\title{
Love, Toil, and Health Insurance: Why American Husbands Retire When They Do
}

\author{
By \\ Joshua Congdon-Hohman
}

June 2013

COLLEGE OF THE HOLY CROSS, DEPARTMENT OF ECONOMICS

FACULTY RESEARCH SERIES, PAPER NO. 11-15*

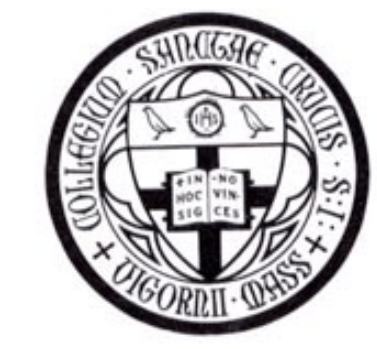

Department of Economics

College of the Holy Cross

Box 45A

Worcester, Massachusetts 01610

(508) 793-3362 (phone)

(508) 793-3708 (fax)

http://www.holycross.edu/departments/economics/website

*All papers in the Holy Cross Working Paper Series should be considered draft versions subject to future revision. Comments and suggestions are welcome. 


\title{
Love, Toil, and Health Insurance: Why American Husbands Retire When They Do *
}

\author{
Joshua Congdon-Hohman ${ }^{\dagger}$ \\ The College of the Holy Cross
}

Version: June 2013

\begin{abstract}
The provision of health insurance has previously been shown to be an important determinant of retirement timing among older Americans, but the existing literature has largely ignored some aspects of the inter-spousal dependence of health insurance benefits. Specifically, the literature examines only how retirement may affect the health insurance available to the potential retiree but not how it might affect a spouse's options. Using data from the Health and Retirement Study, I find that the impact a husband's retirement might have on a wife's health insurance options has a statistically significant impact on a husband's rate of retirement that is independent of considerations of his own health insurance options. In households where the wife is the only one at risk of losing affordable health insurance if the husband retires, the husband is 30 percent less likely to retire than if neither spouse is at risk (a five percentage point decrease in the retirement rate). Based on these findings, prior research is missing one avenue that changes to the Medicare eligibility age and health insurance policy changes through the Affordable Care Act might impact the labor supply of older workers.
\end{abstract}

JEL Classification Codes: I13, J26, J32

Keywords: Retirement, health insurance, household decision-making

${ }^{*}$ Thanks to the Editor, anonymous referees, Charlie Brown, Jeff Smith, Tom Buchmueller and David Albouy for their helpful comments, guidance and support. Additional thanks to Robert Baumann, Melissa Boyle, Nzinga Broussard, Taryn Dinkelman, Ann Ferris, Samara Gunter, Jonathan Lanning, Matthew Rutledge, and seminar participants at the University of Michigan for their helpful input. All errors and omissions are my own.

${ }^{\dagger}$ Department of Economics. Contact via email: jcongdon@holycross.edu. Website: http://college.holycross. edu/faculty/jcongdon/. 


\section{Introduction}

Extensive research has examined the important role of a man's health insurance source on his retirement decision, but this research has not been extended to account for how a husband's retirement might impact the availability of health insurance for a spouse. Though a health insurance source is often extended to both spouses, there are times when a retirement could have a divergent impact on each spouse's access to coverage, such as when one spouse is Medicare eligible and the other is not. Such scenarios have been ignored by the existing literature and provide an opportunity to examine the relative importance of each spouse's needs when households determine the timing of a husband's retirement. For other elements of the retirement decision, researchers have found that the joint benefit of the couple is not always maximized. For example, Sass, Sun and Webb (2007) and Henriques (2012) found that the timing of a husband's initial Social Security claim is more likely to maximize his own expected benefit rather than the joint benefit of the couple. As changes to federal health insurance policy are considered and enacted, the answer to this question could have important implications in regard to labor force exits and, in turn, tax-based revenue and the fiscal conditions of Medicare and Social Security.

In the analysis using extensive data the Health and Retirement Study (HRS) that follows, I present evidence that a strong relationship exists between a wife's health insurance needs and the timing of a husband's retirement, even independently of husbands' own health insurance concerns $1^{1}$ Consistent with previous research, I find that the retirement rate for husbands who would lose their low cost health insurance source upon retirement (regardless of whether their wives would as well) is six to nine percentage points lower than for those who would not. Not examined in previous research is a similar decline of five percentage points

\footnotetext{
${ }^{1}$ Though the HRS is the richest dataset for Americans in this age range currently available, the number of respondents does not allow for a parallel analysis of the relationship of spousal health insurance and the retirement of women due to the small share of women who receive health insurance from their own employers and even fewer whose husbands also rely on that insurance. The results of a parallel analysis to that which follows is available in the Appendix but it relies on far too few observations in the categories of interest to provide trustworthy insights.
} 
in the rate of retirement among husbands in households where the wife, but not the husband, would lose her current health insurance source without having an observed affordable alternative. $2^{2}$ These marginal effects represent a 30 to 45 percent decline in retirement rates and are not statistically different from each other. Interestingly, the impact on retirement rates of a wife's health insurance options is dependent on her self-reported health while that for the husband's health insurance options is not linked to his health.

In recent years, there have been a number of significant policy changes to the availability and cost of health insurance that have been enacted and others that have been proposed. The potential impact of these policy measures depends on the responses of individuals to changes in health insurance availability. The 2010 health care overhaul legislation, the Patient Protection and Affordable Care Act (ACA), was designed to address both the cost and availability of health insurance to all Americans but especially those who are nearing Medicare eligibility age. Lower cost health insurance alternatives could affect retirement timing and would therefore have fiscal implications in the United States. First, retiring individuals are generally replaced by lower income employees which will negatively affect income tax revenue for the federal government. Second, the financial outlook for the Social Security program is closely linked to the expected rates that individuals move from payers to receivers ${ }^{3}$ In recent years, the full benefit eligibility age of Social Security benefits has been increased to encourage delayed retirement but no similar changes have been made to the Medicare qualifications. The projected impact of the new health care legislation could be substantially different depending on whether the needs of younger spouses are considered. The legislation's goal of making the private, non-group health insurance markets more acces-

\footnotetext{
${ }^{2}$ Appendix Section A presents a basic theoretical example of the problem facing the household and what is missing from previous work on this topic.

${ }^{3}$ Though Social Security benefits are designed to have actuarially fair benefit adjustments for those who retire before or after the normal retirement age, Coile and Gruber (2001) found that there is a small benefit disincentive to working between the ages of 55 and 61 and a large benefit penalty to working between the ages of 65 and 69 for the median male worker. The only benefit reductions for the median male worker that were found to be actuarially fair were for those between 62 and 64 but even those where unfair to almost half of individuals at age 62. Therefore, delays in retirement should improve the fiscal outlook of the Social Security program.
} 
sible and affordable could have implications as households are given access to less expensive alternatives to employer provided health insurance (EPHI). Similarly, recent proposals to change the Medicare eligibility age to 67 (an important proposal in the "Ryan Plan" and other deficit reduction proposals (Kennedy 2011)) could have unexpected implications as workers may work past reasonable ages in order for their spouses to attain Medicare eligibility age. Such changes, if successful, would have fiscal implications for Social Security and general tax revenue that may be underestimated based on the methodology of previous research, especially given the increased reliance on non-group, private insurance and Medicare due to the declining rate that employers are offering health insurance to their potential retirees.

Though previous research has consistently found a link between employer provided health insurance (EPHI) offers and various labor decisions, including retirement, the empirical strategies have been limited to examining just an individual circumstances and not that of a spouse. Papers by Madrian (1994), Karoly and Rogowski (1994), Gruber and Madrian (1995), Rogowski and Karoly (2000), and Blau and Gilleskie (2001) all found a strong link between men's retiree health insurance (RHI) offers and their retirement hazard using reduced-form analyses, but none tested the impact of possible changes to wives' health insurance status $4^{4}$ Similarly, recent extensions in this literature examining the frequency of "joint" or coordinated retirement within dual-earning households by Blau and Gilleskie (2006) and Kapur and Rogowski (2007) also do not account for the influence of spouses' health insurance needs on each individual's decision to retire.5 ${ }^{5}$ Most recently, Kapur and Rogowski (2011) examined differences in the role of health insurance on the retirement decisions of men and women. Though they found an impact of both one's insurance source and

\footnotetext{
${ }^{4}$ Gruber and Madrian (2002) provide a thorough review of the literature and findings, including a number of papers that use structural models to analyze retirement decisions and incorporate individuals' health insurance, but not that of their spouses if they retire. Most prominently, the studies using structural models to identify the role of health insurance in the decision to retire include Gustman and Steinmeier (1994), Lumsdaine, Stock and Wise (1994), Rust and Phelan (1997), and French and Jones (2011).

${ }^{5}$ Kapur and Rogowski (2007) do find that the propensity of simultaneous retirements more than doubles if wives possess RHI, which suggests an important role for health insurance in the timing of retirement within households.
} 
that of a spouse, their approach treated a spouse's employer health insurance offers primarily as an alternative source for the potential retiree. As in other previous research, they did not account for how a retirement might impact the health insurance availability of the spouse directly. Additionally, Kapur and Rogowski (2011) examine only potential retirees prior to Medicare eligibility and do not account for the potential eligibility of a spouse.

Rogowski and Karoly (2000) provide a good example of the common empirical strategy in the literature which examines men's current health insurance sources and the relationship of each to retirement rates. Specifically, they identify five health insurance source categories: EPHI and no RHI offer, EPHI and RHI offer, EPHI and do not know if RHI offer, no EPHI but other private or public health insurance coverage, and no insurance. Health insurance from a spouse's employer is presumably included as an "other" form of private coverage, but nowhere do the authors account for the potential impact of a man's retirement on his spouse. Though spouses' insurance coverage is usually shared, the rules of Medicare eligibility create a discontinuity for spouses of different ages that is not captured by empirical models like those used by Rogowski and Karoly (2000). Due to this omission, the existing literature is not fully capturing the impact of employer provided health insurance. In the analysis that follows, I will use cases where the impact of a husband's retirement differ for each spouse to identify the degree to which households independently consider the impact for each household member 6

One previous study has attempted to address the effect of the inter-spousal health insurance dependency. In trying to isolate the affect of Medicare on mens' retirement, Madrian and Beaulieu (1998) use the difference in ages between spouses to proxy for differences in health insurance availability upon retirements. Madrian and Beaulieu (1998) found an increase in the retirement hazard of 55 to 69 year old men with Medicare eligible wives compared to those whose wives are not Medicare eligible. Because the Census data used in the study did not include health insurance data, it was unable to identify the size of

\footnotetext{
${ }^{6}$ Appendix Section A presents a basic theoretical example of the problem facing the household and what is missing from previous work on this topic.
} 
this influence or compare it to that of the husband's health insurance options because they cannot separately identify those who are constrained by the Medicare qualification age (i.e. those without RHI) and those who are unconstrained. The wealth of detailed data in the HRS allows for the estimation of the impact of cross-spouse health insurance dependency while also controlling for factors other than age that may influence the decision to retire.

Section 2 discusses the health insurance options and current trends for near-retirement married couples in the United States. Section 3 describes the Health and Retirement Study, the sample used, and definitions of key elements for the analysis that follows. Section 4 discusses the general methodology used and addresses some concerns raised in the existing literature. Section 5 presents the main results and a number of specification checks. Section 6 concludes.

\section{Health Insurance and Retirement: Background}

Health insurance provision for working age Americans is centered around EPHI. The majority of workers receive health insurance from either their own or their spouses' employers. In most working couples, both spouses have health insurance through the same employer's plan due to the fact that most group health plans are available to both spouses in a household 7 When Americans reach 65 years of age, they become eligible for the federal government's health insurance program, called Medicare, as long as they have worked ten years in a qualifying job (which most do). Unlike most group health insurance plans that employers might offer to their current and former employees, one's eligibility for Medicare only can be extended to a spouse if that spouse also meets the minimum age requirement (currently 65). Medicare is available prior to that age only for those with qualifying disabilities. Based on the fact that wives are on average two to three years younger than their husbands, the rules of Medicare

\footnotetext{
${ }^{7}$ In near-retirement aged households where the husband is working and both spouses report employer provided health insurance (EPHI), over 87 percent of spouses are on the same plan. Sixty-nine percent of households have a plan through the husband's employer and 18 percent through the wife's. Percentages are based on the author's calculations using the 1992 wave of the Health and Retirement Study.
} 
imply that a large share of wives do not qualify at the same time as their husbands. 8

If workers choose to retire before they reach 65 years of age, they have a number of possible outcomes. For some, their employers offer to continue to provide health insurance to retirees who have worked for the employer for a certain number of years. I refer to this as an offer of retiree health insurance (RHI). The level of premium subsidization depends on the employer's specific benefits but, in general, these programs are retirees' least expensive option due to the risk pooling over all of an employer's employees. Under most RHI plans, spouses of retirees can also be covered, though again, with different levels of subsidization. If retirees do not have an offer of RHI, they may remain on their former employer's health insurance plan for 18 months following separation of employment but they will pay the full cost of the insurance (plus a two percent administration fee). This is commonly referred to as "COBRA" benefits (after the federal Consolidated Omnibus Budget Reconciliation Act of 1985 which granted this benefit). The availability of EPHI and RHI has declined in recent decades as fewer employers are offering these benefits to their employees. According to a 2007 survey of employers, the percentage offering EPHI is down from 69 percent in 2000 to 60 percent in 2007 (Kaiser Family Foundation and Health Research and Education Trust 2007). Similarly, a larger study using Medical Expenditure Panel Survey (MEPS) found that only one-quarter of private-sector employees were working at firms that offered retiree health benefits in 2003 compared to 32 percent in 1997 (Buchmueller, Johnson and Lo Sasso 2006).

Private, non-group health insurance is one alternative to employer-provided health insurance. It is hard to estimate the average cost of such plans because of the high variability in the terms of each policy but they tend to be more expensive than employer-provided health plans with higher premiums, deductibles, and co-payments for services. Until recently, insurance companies in most states retained the option to deny coverage to individuals whom they deem too risky or to limit benefits for pre-existing conditions. Examination of insurance

\footnotetext{
${ }^{8}$ For a distribution of the gap in ages between spouses in the Health and Retirement Study, see Appendix Figure 1 .
} 
companies' offer rates have found that companies reject 10 to 14 percent of all applicants (Pauly and Nichols 2002, Merlis 2005) and up to 37 percent of those with pre-existing conditions (Pollitz, Sorian and Thomas 2001). The ACA addresses the problems of accessibility and limited coverage by prohibiting health insurance companies from using previous health issues when evaluating an application and by standardizing coverage in the newly established health insurance "Exchanges" (Kaiser Family Foundation 2011).

If near-retirement aged individuals choose to go without insurance, they face higher medical costs on average than younger Americans, with much higher variability. Tabulations from the MEPS show the 2005 mean medical expenditure for individuals between 55 and 64 years of age to be over fifty percent higher than for individuals between the ages of 45 and 54 at $\$ 5923$ and $\$ 3775$, respectively $\left.\right|^{9}$ Under the ACA, those who choose to go uninsured could also face a financial penalty. The penalty for not maintaining "minimum essential coverage" would start at $\$ 95$ or one percent of income in 2014 and increase to $\$ 695$ or 2.5 percent of income in 2016 with cost of living adjustments made after 2016 (Kaiser Family Foundation 2011).

\section{Data, Definitions, and Descriptive Analysis}

The analysis that follows uses detailed longitudinal data on a nationally representative sample of American households from the Health and Retirement Study (HRS). The initial cohort of the HRS included households where at least one member was between the ages of 51 and 61 in 1992. A new cohort, labeled the War Baby Cohort, was added in 1998 and includes households in which one spouse was between the ages of 51 and 56 at the time of their first interview. The HRS includes data from re-interviews that occur every two years and the results will be based on the 1992 through the 2006 interview waves. The data used in this study are available from the Institute for Social Research at the University of Michigan and

\footnotetext{
${ }^{9}$ This calculation is similar to an earlier calculation by Gruber and Madrian (1996). MEPS data is available through the U.S. Department of Human Services' Agency for Healthcare Research and Quality at http://www.meps.ahrq.gov/mepsweb/index.jsp.
} 
the RAND Center for the Study of Aging (see St. Clair (2008) for a description of the RAND data files).

The sample from the HRS used in the following analysis will be restricted in a number of ways. There are 6,875 households represented in the HRS where at least one household member is age eligible for one of the two cohorts identified above. Those households are interviewed a total of 34,440 times. Table 1 itemizes the sample restrictions and the number of households and observations that remain after each. The sample is limited to only married couples in order to focus on the inter-dependence of health insurance. To focus on the act of retirement, the sample is further limited to only households where the husband is working and has not previously retired at the time of the initial interview 10 The latter restriction is based on the concern that jobs following a retirement reversal may not be similar to preretirement jobs and that those who have retired previously might have unobserved differences from those who are considering retirement for the first time. Those who are self-employed are also excluded due to the complicated relationship between benefits and employment when one is running his own business.

The final general restriction on the sample is that one of the spouses in each household must report health insurance from a current employer. This restriction is made in part to address endogeneity concerns in regard to employees selecting into jobs that provide health insurance due to a greater valuation of that benefit. The selection concern will be discussed further in Section 4 below. Ultimately, the analysis sample includes data from 3,044 independent households and 8,417 observations (or 2.75 observations per household) after a number of observations and households are lost due to data availability. Though not representative of the whole population, the sample does represent those who are most likely to respond to changes in health insurance policy and therefore the population of interest for the questions being addressed in this study.

Past literature has used varying definitions of retirement (see Karoly and Rogowski (1994)

\footnotetext{
${ }^{10}$ Re-entry is quite common as shown by Maestas (2010) and Congdon-Hohman (2006).
} 
for a discussion of various definitions). This study defines retirement as moving from a working, non-retired classification in the current wave (full-time or part-time work) to a retired labor force status in the following wave (partial or full retirement). Following the methodology used in the RAND data files and many other studies, the identification of retirement is based on the hours and weeks worked by a respondent and their self-identified retirement status. Those who work full-time (defined as 35 hours or more per week and at least 36 weeks in the last year) will not be considered retired regardless of their self-designation. Those working part-time will be identified as retired if they self-identify as "retired" and identified as not retired if they do not. Finally, anyone not working and reporting being "retired" will be identified as retired while those not working and not identifying themselves as retired (the unemployed, disabled, and those not in the labor force but not retired) will be excluded from the sample 11

It is important to carefully categorize the health insurance circumstances of a couple and how I define expectations for health insurance provision if the husband were to retire between the current and the following wave. Since I am studying the link between health insurance and labor force transitions, it is important to identify alternative sources of insurance that may not be linked to continued employment. Affordable alternatives to EPHI from the husband's employer include offers of RHI, Medicare, or EPHI through a wife's employer. Therefore, I will identify a husband as "at risk" of losing his low-cost health insurance upon retirement if he reports that his employer offers EPHI but does not offer RHI, his wife does not receive EPHI from her current or former employer, and he will be under 65 as of the next wave. All three conditions must hold in order for a husband to be classified as "at risk." Similarly, I will identify a wife as "at risk" if her current health insurance source is her husband's employer, that employer does not offer RHI, and she will be under 65 years

\footnotetext{
${ }^{11} \mathrm{~A}$ weakness of this definition is that an individual working part-time can change their classification to "retired" without changing their work level since the difference between the two categories is purely based on self-reported retirement status. The same is not true for a full-time worker since the definition does not allow a full-time worker to be classified as "retired." The results are generally similar to the findings below using different definitions of retirement such as considering only "full-time work" as a non-retired status or full-retirement as the only retired status.
} 
of age at the time of the next wave ${ }^{12}$

Table 2 lists the qualifications one must have to be classified as "at risk" and the percent of the examined sample that is potentially at risk based on each. Within the analysis sample described above, the age qualification only makes up a small part of the risk categorization as most respondents in the analysis sample will be under 65 years of age in the following wave (91 percent of men and 95 percent of women) and thus assumed to be ineligible for Medicare ${ }^{13}$ Amongst the men, almost eighty percent identify their employer as their health insurance source with thirty percent not being offered retiree health coverage. Sixty-two percent of the men in the analysis sample do not report a spouse having EPHI from her own employer and thus does not appear to have her employer's insurance as an alternative to his own employer's (more on this in a moment). Overall, 20.2 percent of the men in the analysis sample are identified as at risk. The numbers are similar for women except that their risk is primarily determined by whether they rely on their husband's employer who offers health insurance only to current employees. About 21 percent of wives report health insurance through such a source and the final percentage of women deemed at risk is reduced slightly to about 20 percent when the 65 years of age restriction is added.

One weakness of the HRS is that it does not ask respondents whether they have declined EPHI from their employer. Therefore some individuals may be identified as "at risk" despite the fact that wives' employers offer EPHI to their employees if those offers were not accepted. These occurrences should be relatively rare as prior research by Buchmueller and Valletta (1999) has shown that EPHI from a husband's employer makes it significantly less likely that a wife will seek out employment with the same benefit even when conditioning on fulltime employment. Regardless, these instances of misclassification should bias our results toward zero since individuals who are not truly at risk of losing their health insurance upon

\footnotetext{
${ }^{12}$ The assumption that wives are eligible for RHI if the husband reports RHI is based on survey results that find this to be the case 91 percent of the time (Kaiser Family Foundation 2002).

${ }^{13}$ The use of age 65 in the following wave as the cutoff for defining risk is adjusted to incorporate the possibility that COBRA continuation benefits as an insurance bridge from the husband's retirement to their 65th birthday and Medicare eligibility in Appendix Section C.
} 
retirement are classified as "at risk." If a wife's employer offers EPHI, the results of past studies suggest that a husband would be more likely to retire. Therefore, any real negative impact on retirement rates due to the risk of losing health insurance will be somewhat masked by those who are retiring at the same rate as those identified as "not at risk" due to the unaccounted for alternatives.

Though husbands and wives have similar rates of being categorized as "at risk," there is some variation within the household. The first column of Table 3 presents the rates that husbands and wives are identified as being "at risk" in an observation wave. Though each spouse has similar individual rates of risk (between 20 and 21 percent), the risk is only shared about 85 percent of the time. The husband is alone at risk and the wife is alone at risk within the household in about three percent of the analysis sample each while 17.5 percent of the sample includes households where both spouses are at risk. ${ }^{14}$ The second column of Table 3 provides retirement rates by risk categorization. The husband's retirement rate is relatively similar in households where the husband alone or both spouses may lose their health insurance if he retires but is much higher if only the wife is at risk. This suggests that a wife's health insurance circumstances have less influence than the husband's on the timing of a husband's retirement and may be in the opposite direction. I test in the analysis that follows whether this continues to be true when other demographic and household characteristics are taken into account.

A look at characteristics across risk groupings will help further elucidate how these groups are defined. Table 4 examines the mean values for each of the four exclusive categories and identifies any statistical differences between each "at risk" category and the case where neither spouse is identified as at risk. The preclusion of risk for those who will be 65 or older leads to differences in age for each at risk category when compared to those where neither

\footnotetext{
${ }^{14}$ Not reported in this table are the transitions for households over time. Of the households in the sample, over one-fourth are classified as having both spouses at risk, almost 14 percent as having the wife only at risk, and 7 percent as having the husband only at risk at some point in the observation period. Many of these households (6.5 percent of the total) change at risk categories over time, with the largest percentage observed in the both at risk and wife only at risk categories.
} 
spouse is identified as at risk. In household's where only the husband is at risk, age plays less of a critical role in defining risk since women tend to be the same age or younger than their husbands. Here, other forms of coverage play a larger role in differentiating the risk within the household. Since Medicare eligibility due to a disability is one such coverage, a larger proportion of wives report poor or fair health in the case of this type of risk than in the other categories. Additionally, households where the spouse is retired are more likely to be identified as at risk since a retired wife cannot provide an alternative health insurance source for the household. Other demographic differences include differences in the pension offer rates and educational attainment of the spouses across risk groups 15

\section{Empirical Methodology}

Like much of the literature referenced earlier, this paper focuses on reduced form analysis to study the relationship of health insurance and retirement decisions. Though there is also a large literature that employs a structural approach to similar questions, I have opted for the reduced form approach primarily for its simplicity and clarity. Previous structural models are extremely complex without introducing the wife's insurance needs to the analysis. As Kapur and Rogowski (2007) stated in their analysis of joint retirement, the interpretive advantages of a reduced-form analysis outweigh the potential predictive gains available with a structural model, which I believe is particularly true when looking at a complex question like this one for the first time.

Though health insurance offers have been used extensively as an independent variable in prominent economic studies of labor force decisions, there is a question as to the appropriateness of using these offers in reduced-form studies due to concerns over its possible endogeneity. Specifically, endogeneity may be a concern if those with a preference for early

\footnotetext{
${ }^{15}$ Generally, those households with some risk have lower educational attainment levels and lower pension offer rates. The differences in the pension offer rates between at risk categories is driven by differences in the offer rates of defined benefit plans. Defined benefit plans are offered at similar rates in both the at risk and neither at risk categories, but at much lower rates in the cases where only one spouse is at risk.
} 
retirement select into jobs that offer RHI. Additionally, RHI may be correlated with other, unobserved qualities of a job. Recently, a number of researchers have rejected the endogeneity concern when conditioning on offers of EPHI both on a practical basis and with specification checks. Kapur and Rogowski (2007) make three main arguments for not being concerned about the possible endogeneity of retiree health insurance. First, Gustman and Steinmeier (2001) and Schur, Berk, Wilensky and Gagnon (2004) provide evidence that individuals are not well informed about their retiree health benefit packages, which suggests a lack of planning for early retirement. Second, most employers require ten years or more of tenure to qualify for RHI, which would require job changes prohibitively far in advance of an expected retirement (Kaiser Family Foundation and Hewitt Associates 2004). Third, retirement planning is difficult because retiree health insurance has been scaled back dramatically in the last two decades and thus, there is no guarantee that RHI will still be available when an individual retires. Unlike pensions which are insured through the federal government, no legal requirement or guarantee exists to maintain retiree health benefits offered before retirement. Additionally, Strumpf (2010) conducted a number of specification checks to support her use of RHI as an independent variable and found no evidence that RHI was endogenous conditional on offers of EPHI ${ }^{16}$ To address these concerns, I limit the sample studied to those households where at least one spouse receives EPHI from a current employer and include a specification using a number of job characteristics to control for job quality. Additionally, the analysis is repeated for various subsamples in an attempt to address other concerns regarding possible unobserved variation that may be correlated with risk categories.

In the section that follows, I present the results from three parallel probit analyses examining the retirement of a husband between the current wave (time $t$ ) and the following wave $($ time $t+1)$ with household-wave pairs as the observation level ${ }^{17}$ In the baseline specification (Specification 1), the only health insurance variable included is the husband's risk of losing low-cost coverage if he retires before the following wave. With this specification, households

\footnotetext{
${ }^{16}$ Strumpf's robustness checks included reanalysis on subsamples of those with over twelve years of tenure and those over four years from retirement when first observed.

${ }^{17} \mathrm{I}$ cluster observations at the household level in order to report the correct standard errors.
} 
where only the wife is at risk of losing her health insurance upon a husband's retirement are included with the control group along with households where neither spouse is at risk. This specification is consistent with the analyses done in previous research. The second specification (Specification 2) adds a control for whether the wife alone is at risk of losing her health insurance if her husband retires before the following wave. This specification is meant to address the question of whether households include the wife's health insurance circumstances when deciding on the timing of the husband's retirement. Additionally, the control group is more logically limited to only those households where neither spouse is at risk of losing his or her health insurance if the husband retires. The third specification (Specification 3) separately identifies households where both spouses, only the husband, or only the wife may lose their low-cost health insurance, which allows me to examine the relative importance of each spouse's risk. The following equations present the specifications more formally:

$$
\begin{gathered}
P\left(\mathrm{RET}_{H, t+1}\right)=\Phi\left(\alpha_{0}+\alpha_{1} H I_{H, t}+\alpha_{4} X_{B, t}+\alpha_{5} W_{t}\right) \\
P\left(\mathrm{RET}_{H, t+1}\right)=\Phi\left(\beta_{0}+\beta_{1} H I_{H, t}+\beta_{2} H I_{\mathrm{WO}, t}+\beta_{4} X_{B, t}+\beta_{5} W_{t}\right) \\
P\left(\mathrm{RET}_{H, t+1}\right)=\Phi\left(\gamma_{0}+\gamma_{1} H I_{B, t}+\gamma_{2} H I_{\mathrm{HO}, t}+\gamma_{3} H I_{\mathrm{WO}, t}+\gamma_{4} X_{B, t}+\gamma_{5} W_{t}\right)
\end{gathered}
$$

In these specifications, $\mathrm{RET}_{H, t+1}$ is an indicator for the husband's $(\mathrm{H})$ retirement before the next wave $(t+1), H I_{H, t}$ indicates whether the husband is "at risk" of losing his health insurance if he retires before the next wave (regardless of his wife's risk) based on his current health insurance source (at time $t$ ) and age at the time of the next wave (at time $t+1)$, $H I_{\mathrm{HO}, t}$ and $H I_{\mathrm{WO}, t}$ indicate that only the husband (HO) or only the wife (WO) is at risk, and $H I_{B, t}$ indicates both spouses are at risk. The $X_{B, t}$ variable represents additional factors (as measured in the current wave, with the exception of age) that may be associated with a husband's decision to retire. Included in $X$ are the wife's current retirement status, the household's non-housing wealth, each spouse's level of educational attainment, and each spouse's age at the time of the next wave. Additionally, $X$ includes indicators for whether the husband has a pension plan from his employer, whether each spouse will be between 
62 and 64 years of age or age 65 and older at the next wave, and whether each spouse currently rates their health as poor or fair (on a five point scale) ${ }^{18} W_{t}$ represents a series of dummy variables for each wave of the HRS and is included to capture any time trends in the dependent variable 19 Additional specifications include other factors as control variables.

The results that follow are presented as mean marginal effects (MMEs) rather than probit coefficients or marginal effects at the mean. Mean marginal effects are simply the average of the calculated marginal effects of a change in the variable of interest (from zero to one if binary or a one unit change if continuous) for each individual in the sample if all other covariates are as reported. By contrast, marginal effects at the mean are the calculated marginal effects if all covariates are evaluated at their mean value. The marginal effects at specific valuations of the key independent variables are also provided for comparison purposes.

\section{$5 \quad$ Estimation Results}

Table 5 presents the results from the probit analyses outlined in the previous section. Columns 1 through 3 present the mean marginal effects (MMEs) when other covariates (the above $X$ 's) are excluded. The results in these columns reflect the surprising pattern from Table 3 that the MMEs of both spouses being at risk and the husband alone being at risk are of a similar magnitude, while the wife's sole risk is associated with a significant increase in the retirement rate. Again, in order to be classified as "at risk" of losing health insurance if the husband retires, a husband must report EPHI but not RHI, not have a wife with EPHI from her own employer, and be under 65 years of age in the next wave. For wives to be at risk, they must report their husbands' employer as their source of EPHI with no

\footnotetext{
${ }^{18}$ Replacing the pension term with separate indicators for the type of pension plan (defined contribution, defined benefit, or both) results in slightly smaller estimates but do not change the findings. Those results are shown in Appendix Table 4.

${ }^{19}$ The mean marginal effects (MME's) for the wave indicators from the probit analysis are omitted in the tables below in order to save space. The MME's of the wave dummies are generally not significant at traditional levels.
} 
offer of RHI and be under 65 in the next wave.

Columns 4 through 6 of Table 5 duplicate the estimations presented in columns 1 through 3 with the addition of covariates. Column 4 (based on Specification (1)) presents the results if a wife's health insurance risk is not explicitly considered. A husband's "risk" of losing affordable health insurance if he retires is associated with a 6.6 percentage point decline in the retirement rate, which is significant at the one percent level. Given that the sample retirement rate is 16.6 percent, this implies a 40 percent drop. The seven percentage point decline in husbands' retirement rate if they stand to lose their health insurance is consistent with previous estimates of the impact of retiree health insurance found in Madrian (1994) (seven to 15 percent decline in likelihood of retiring before a man reaches 65), Karoly and Rogowski (1994) (eight percentage point decline in retirement rate for men without RHI), Rogowski and Karoly (2000) (a eleven percentage point increase in the predicted retirement probability with an offer of RHI), and Blau and Gilleskie (2006) (eight percentage point difference in labor force exit for men with and without RHI).

Column 5 of Table 5 presents the results for Specification (2), which adds an indicator for the wife only being at risk. Despite separating the households where the wife alone is at risk of losing her health insurance from the comparison group, the MME of the husband's risk is left unchanged. The addition of covariates changes the MME of the wife's exclusive "risk" from positive to significantly negative since this category is no longer proxying for the case where the husband will be over 65 years of age in the next wave and thus highly likely to retire ${ }^{20}$ Taken together, these results support the estimates the previous literature examining the impact of a husband's own health insurance concerns but also show that households consider wives' risk of losing health insurance independently when choosing the timing of retirements which has been not been previously identified. As discussed earlier, the trend in RHI offers may increase the importance of this omission in the near future

\footnotetext{
${ }^{20}$ The fact that the health insurance risk MMEs change when other factors are included may raise concerns about the endogeneity of the health insurance indicators. Appendix Section B explores this question and finds the addition of the husband's age to be the most significant factor in the differences in the MMEs reported in Table 5
} 
depending on the implementation of the ACA and any changes to Medicare eligibility ${ }^{21}$

To identify whether each spouse's health insurance risk is equally weighted in household decision making, I next separately identify households where only the husband is at risk and both spouses are at risk (Specification (3)). The results in column 6 of Table 5 show the MME of all the risk indicators are negative and significant at the five percent level. The indicator for the husband's sole risk (a negative ten percentage point marginal effect on average) is about 60 percent larger than the MME for both at risk (negative six percentage points). Despite the fact that the husband's sole risk MME is almost twice that of the wife's (negative 5.2 percentage points), the hypothesis that the two MMEs are equal cannot be rejected at the ten percent level based on the results of a Wald test. The larger MME for husband's sole risk exemplifies the issue of unobserved health insurance offers from a wife's employer and the resulting underestimates of the impact of health insurance risk in the cases of wife only and both spouses at risk. In those cases, an accepted offer from the husband's employer may mask an unaccepted offer from the wife's employer. This is less likely in the case where the husband only is at risk since the wife's health insurance source has been identified as non-employer based and therefore the wife is unlikely to have such an offer.

The MMEs of the other covariates are generally as one would expect based on previous literature. Table 5 shows that having a currently retired wife, a pension plan and each additional year of age have a positive association with future retirement and are significant at the one percent level. ${ }^{22}$ Reaching the key ages of 62 (when he first qualifies for reduced Social Security benefits) and 65 (when he becomes eligible for Medicare and unreduced Social Security benefits) before the next wave are also associated with large increases in the retirement rate. Though mostly insignificant, a wife's age at the next wave is also associated with an increase in the rate of retirement while key milestone ages of 62 and 65 for wives are

\footnotetext{
${ }^{21}$ Appendix Table 5 presents the results if wives' retirements are examined instead of husbands' retirement. As discussed earlier, the small number of cases where a husband is alone at risk makes these results uninformative.

${ }^{22}$ Pension benefits and spousal retirements could potentially have similar endogeneity concerns as those discussed above in regard to retiree health insurance offers. The inclusion of these controls has only a minimal impact on the health insurance MMEs that are the focus of this paper.
} 
negatively associated with a change in the husbands' retirement rate. If a husband reports his health as fair or poor, he is significantly more likely to retire, but not if the wife rates her health as fair or poor.

Though MMEs give an overview of the impact of each risk category by looking at the average impact over the full sample, it is also interesting to look at the impact of each risk category at various points in the sample. Table 6 presents the marginal effects for the three risk categories from Specification (3) evaluated at various values of key covariates with other covariates valued at their means. The first panel examines the marginal effects for different age pairings of the couple. At the mean values for those ages (59.4 is rounded to 59 for husbands and 56.2 is rounded to 56 for wives), the marginal effects are slightly lower than the MMEs reported in Table 5, though all still significant at the five percent level. For each spouse, the marginal effects for all risk identifiers decrease as age increases by one standard deviation but the scale of change is much smaller as the wife ages compared to the husband. The marginal effects for all risk identifiers decrease by over two percentage points with each standard deviation change in the husband's age but decrease by only 0.2 percentage points for a similar change in the wife's age. When evaluating the marginal effects of the risk identifiers at various levels of other key controls, Table 6 shows that their negative impact is greater for those husbands whose wives are retired, are not offered a pension, and who report being in fair or poor health. Changes to a wife's health and the household's nonhousing wealth have little impact on the marginal effect of the health insurance risk facing the households.

One reason for the large difference in the MMEs for a husband's and wife's sole health insurance risk may be the differences in financial costs of health care and insurance associated with each gender. In the age range examined in this study, women tend to be healthier than men and to have lower medical costs which result in lower non-group insurance premiums. If this difference is an important factor that has been missed in the above analysis, I would expect that the marginal effect of the risk of losing health insurance for women would be more 
similar to that of men when differences in health are better controlled for. Table 7 presents results when interacting the self-reported health measure with the health insurance risk categories used above. The MME in column 1 are replicated from the original specification in Table 5. Column 2 presents the results when the health measures are interacted with the appropriate health insurance risk indicator (e.g. the wife's sole risk is interacted with the wife's health measure). The inclusion of interaction terms has very little impact on the health insurance MMEs that involve the husband, but has a modest impact on the MME of the "wife only at risk" category. The inclusion of interaction terms decreases the magnitude of this MME by one percentage point and reduces the significance below traditional thresholds (from a significance level of five percent to just above ten percent). The opposite is true of the MMEs of the interaction terms ${ }^{23}$ Though they are generally negative, only the MME of the interaction term of the wife's self-rated health and the wife only at risk identifier is significant at traditional levels. This pattern seems to suggest that households are concerned about the husband's health insurance generally but consider the wife's primarily when she is in poor health. This pattern does not persist if other, more quantitative measures of health are used in place of self-rated health quality measures (see Appendix Section $\mathrm{D}$ where the existence of health conditions and hospital stays are substituted for self-rated health).

Given that the distinction between risk categories are primarily identified by the relative ages of spouses, one may be concerned that couples with different age gaps may have other differences that are not captured in the controls. If this is the case, the fact that a large age difference between spouses will result in a higher likelihood of being identified as at risk, our individualized risk categories may be simply proxying for this age difference. To address this concern, I separately run the primary analysis on two subsamples where the wife is substantially younger than her husband. Columns 1 and 2 of Table 8 presents the results of this analysis. The two subsamples of households are those where the husband is 3 to 5 years older and those where the husband is 6 years older or more. The results show a pattern which

\footnotetext{
${ }^{23}$ The MMEs and standard errors for interaction terms reported in Table 7 have been adjusted to reflect the true magnitude of the interaction term's marginal effect described in Ai and Norton (2003).
} 
is consistent with earlier results. In these subsamples, households where the wife is at risk of losing low cost health insurance if the husband retires are six to seven percentage points less likely to retire than similarly situated families without the risk of losing health insurance. The impact of the husband's sole risk is also more pronounced in these subsamples. These results suggest that the risk variables are not proxying for the age gap between spouses.

Columns 3 and 4 of Table 8 present the results of an alternative approach to identify the impact of health insurance through a spouse. Rather than use the data as a panel, I instead take a cross-section of data at the time when health insurance access for each spouse if a husband retires will be most divergent: before and after the husband becomes Medicare eligible. For each household, I take only the wave before the husband turns 65 and identify whether he has retired before the next observation wave. Column 3 presents the results when a probit analysis continues to be used. Since the husband will be 65 when next observed, he cannot be "at risk" so his risk variables have been dropped. By limiting the examination to one risk category, it is now possible to further assure the appropriateness of our comparison group by using propensity score matching where each observation is matched by the propensity of the wife being identified as at risk based on the couple's observable qualities. Column 4 presents the results of using a propensity score matching approach and presents the average treatment effect on the treated (ATT) ${ }^{24}$ Using the same controls as in the earlier analysis other than age categories for the husband, the MME in column 3 and ATT in column 4 are larger than the 5 percent found in our baseline model and significant at traditional levels. Though the magnitude is greater, these values are similar to earlier results in percentage terms since the retirement rate in this subsample is much larger than the whole sample at just under 43 percent. The 12 to 13 percentage point decrease in the likelihood of retirement associated with a wife's risk of losing health insurance represents about a 30 percent decrease and is consistent with the earlier findings.

\footnotetext{
${ }^{24}$ Observations are matched using the radial approach where the radius is set to 0.1. Propensity scores are determined based on the same observable qualities used in the primary analysis and meet the balancing property. The alternative approaches using nearest neighbor and stratified matching provide similar ATT values.
} 
To examine the concern that health insurance may be acting as a proxy for job quality, Table 9 presents the MMEs of a probit analysis when a large number of the husband's job characteristics are included. Specifically, I include a number of the husband's reported job requirements (the husband reports that his job "always" or "most of the time" includes "physical effort," "good eyesight," "intense concentration," and "people skills") and characterizations of his job (the respondent "strongly agrees" or "agrees" that his job's tasks are "difficult," the job has "a lot of stress," older workers feel "pressure to retire" or are given "less demanding tasks," and whether he "enjoys" his work). The sample is limited to waves 3 through 8 due to the fact that questions about the enjoyment of work were not asked in the second wave of the HRS. Columns 1 and 2 of Table 9 show very little impact on the key MMEs when the second wave is dropped from the sample used in the original specification. Columns 3 through 4 show that though a number of job characteristics are associated with significant differences in the retirement rate of husbands, their inclusion does not have a marked effect on the MMEs of the risk indicators. Thus, Table 9 is evidence that health insurance risk is not acting as a proxy for job quality.

\section{Conclusion}

Economic literature focusing on the retirement of near-elderly men has largely omitted controls for the health insurance implications of husbands' retirements for their wives. The results of this study suggest that households do consider the health insurance circumstances of both spouses when choosing the timing of a husband's retirement. I also find that the risk that a wife might lose the opportunity of low-cost health insurance has a similar impact on husbands' rate of retirement as the risk of a husband losing his own insurance, especially once thoroughly controlling for a wife's health. In households where the wife is the only one at risk of losing affordable health insurance if the husband retires, the husband is 30 percent less likely to retire than if neither spouse is at risk (a five percentage point decrease in the re- 
tirement rate). These findings are similar to a previous finding that husbands are responsive to their wives' pension benefits when making individual labor force decisions (Coile 2004) and counter to other research that has shown men do not fully consider the impact of decisions on their spouses. The implications of these findings for the economic modeling of household decision making is that both spouses' financial and health insurance circumstances must be considered in order to correctly account for the full incentives that individuals face with regards to health insurance and labor supply. Though the current literature accurately accounts for a husband's responsiveness to his own health insurance options, it fails to fully account for the incentives men face when they have younger, non-Medicare eligible spouses and no offer of RHI.

If it does not already do so, future policy analysis should take care to incorporate the effects for both an individual and his or her spouse when evaluating the impact of the reformed health insurance market and any possible changes to the Medicare program to improve its financial solvency. If the current trend of declining RHI offer rates continues or accelerates due to the passage of the ACA or similar legislation, a failure to include the effects of policy changes on a spouse may underestimate the impact on men's retirement rates. For example, new regulations to make private, non-group health insurance more affordable and accessible will not only move forward the retirement of those who would have otherwise waited to become eligible for Medicare, but also those who formerly appeared to be unresponsive to their own health insurance incentives because they were waiting to retire until their wives turned 65 as well. 


\section{Appendices}

\section{A Theoretical Motivation}

Appendix Figure 2 shows a graphical representation of a husband's labor-leisure optimization problem when health insurance is tied to employment. For ease of analysis, I assume the wife's labor supply decision has already been made and the household is choosing the husband's labor supply to maximize its utility given the household budget constraint. One could imagine that this is the result of a common preference approach to family behavior (such as models based on Samuelson (1956) or Becker (1974)) in which an employment decision for the wife is made first. Alternatively, the optimization problem presented here could represent the decision faced by a husband in a Nash bargaining framework where each spouse takes the other's actions as given. This framework is common in much of the literature on cooperative family bargaining models 25

In this example, households have some level of income not earned by the husband in the current period (which may include income earned by the wife) and the value of any benefits not linked to on-going employment. Husbands can earn a constant wage for each hour of leisure they relinquish for labor. Because EPHI is usually a benefit offered only to full-time employees, the representation of the household's budget constraint is discontinuous at the point where the husband would be considered a full-time employee. The height of the kink could be thought of as the cost of non-group health insurance, as the expected additional medical costs to the household if not insured, or as the amount the household is willing to pay to avoid the risk of extremely large medical costs due to a negative health shock ${ }^{26}$ The solid black line in Appendix Figure 2 represents the budget constraint for a household where both

\footnotetext{
${ }^{25}$ For a more detailed discussion of the models of household decision making, see Lundberg and Pollack (1996).

${ }^{26}$ Though not represented in Appendix Figure 2, other benefits (pecuniary and non-pecuniary) for fulltime workers would simply increase the size of the kink at full-time work while maintaining the less than full-time representations of the possible budget constraints.
} 
spouses rely on the husband's employer for EPHI. By this, I mean that if the husband were not to work full-time, both the husband and the wife would be left with the choice between only high-cost private, non-group health insurance or going uninsured (because they do not have the options of Medicare, EPHI from the wife's employer, or RHI from the husband's employer).

The size of the kink in the budget constraint depends on how many household members are dependent on the husband's EPHI. In couples where the husband has retiree health insurance coverage, insurance through the wife's employer, or both spouses are eligible for Medicare, the budget constraint would be continuous because there is no added value of working full-time other than additional wages. This scenario is represented in Appendix Figure 2 as the fully linear budget constraint where the unearned income is the total of noncurrent employment-based income and the value of health insurance for both spouses. The budget line with a smaller discontinuity represents the case where only one spouse does not have an alternative health insurance source (for example, when only one spouse is eligible for Medicare). Prior research has excluded this case when examining the decision of men to retire.

Based on the depiction in Appendix Figure 2, individuals will maximize their utility $\left(U_{0}\right.$ and $U_{1}$ represent indifference curves where $U_{1}>U_{0}$ ) by choosing full-time employment if both spouses rely on the husband's employer for health insurance. If the husband becomes eligible for Medicare and the wife does not, the shape of an individual's indifference curve will determine whether the husband would maximize the household utility by continuing to work full-time or by reducing his labor. As depicted in Appendix Figure 2, a husband who becomes eligible for Medicare while his wife does not would still maximize the household's utility by working full-time. Models that do not include this intermediary case would predict that the husband would reduce his labor and may construe the lack of that response as unresponsiveness to health insurance incentives. 


\section{B Decomposition of the Impact of Covariates on Key Mean Marginal Effects}

The fact that the health insurance risk MMEs change in Table 5 when other factors are included may raise concerns about the endogeneity of the health insurance indicators. To answer this concern, the lower panel of Appendix Table2 2 shows the contribution of additional covariate groupings using the values from analogously defined ordinary least squares (OLS) specifications. The upper panel of Appendix Table 2 presents the equivalent OLS results to Table 5 and shows the OLS estimates to be very close to the MMEs from the probit analyses. Using specification (2) as an example, the values in the lower panel were arrived at through the following series of equations ${ }^{27}$

$$
\begin{gathered}
\operatorname{RET}_{H, t+1}=a_{0}^{A}+a_{1}^{A} H I_{\mathrm{H}, t}+a_{2}^{A} H I_{\mathrm{WO}, t}+\varepsilon^{A} \\
\mathrm{RET}_{H, t+1}=a_{0}^{B}+a_{1}^{B} H I_{\mathrm{H}, t}+a_{2}^{B} H I_{\mathrm{WO}, t}+a_{3}^{B} X_{B, t}+\varepsilon^{B} \\
x_{1}=b_{1}+b_{1}^{h} H I_{\mathrm{H}, t}+b_{1}^{w} H I_{\mathrm{WO}, t}+\varepsilon_{1} \\
x_{2}=b_{2}+b_{2}^{h} H I_{\mathrm{H}, t}+b_{2}^{w} H I_{\mathrm{WO}, t}+\varepsilon_{2} \\
\vdots \\
x_{r}=b_{r}+b_{r}^{h} H I_{\mathrm{H}, t}+b_{r}^{w} H I_{\mathrm{WO}, t}+\varepsilon_{r}
\end{gathered}
$$

In the above equations, variables are labelled as in Section 4 where $X=\left(x_{1}, x_{2}, \ldots, x_{r}\right)$ and $r$ is the number of additional covariates. Substituting equations (6) into equation (5) and collecting terms produces the following:

$\operatorname{RET}_{H, t+1}=b^{B}+\sum_{k=1}^{r} a_{3, k}^{B}\left(b_{k}\right)+\left(a_{1}^{B}+\sum_{k=1}^{r} a_{3, k}^{B}\left(b_{k}^{h}\right)\right) H I_{\mathrm{H}, t}+\left(a_{2}^{B}+\sum_{k=1}^{r} a_{3, k}^{B}\left(b_{k}^{w}\right)\right) H I_{\mathrm{WO}, t}+\left(\varepsilon^{B}+\sum_{k=1}^{r} a_{3, k}^{B}\left(\varepsilon_{k}\right)\right)$

\footnotetext{
${ }^{27}$ Though not included in the equations here, wave dummies continue to be included at every stage.
} 
Therefore, the change in the coefficients of interest can be decomposed as

$$
\begin{aligned}
& a_{1}^{A}-a_{1}^{B}=\sum_{k=1}^{r}\left(a_{3, k}^{B}\left(b_{k}^{h}\right)\right) \\
& a_{2}^{A}-a_{2}^{B}=\sum_{k=1}^{r}\left(a_{3, k}^{B}\left(b_{k}^{w}\right)\right)
\end{aligned}
$$

Each term on the right hand side of Equation (8) can be interpreted as the individual impact of the inclusion of that covariate on the change in the coefficient of interest. For example, the value for the contribution of the age variables is arrived at by taking the $\sum_{j=1}^{m}\left(a_{3, j}^{B}\left(b_{j}^{h}\right)\right)$ for the $m$ factors related to age ${ }^{28}$ The bottom panel of Appendix Table 2 shows that almost all of the change in the health insurance risk coefficients is due to the inclusion of age variables and not spouse's retirement status, pension, wealth, health or education. If pensions or education had been large contributors to the difference in the health insurance risk MMEs, I would be concerned about other factors that this specification is not accounting for that may be associated with both the decision to retire and health insurance risk. The above analysis does not imply that health, wealth, pensions and education are not associated with a husband's decision to retire, just that their inclusion does not have a major impact on the coefficients associated with health insurance risk.

\section{Incorporating COBRA into the Definition of Heath Insurance Risk}

One might also be concerned that employer continuation benefits have not been included in the definition of health insurance risk. Under federal law, employers with over 20 employees are required to allow separated employees who have EPHI to remain in their current health insurance plan, at 102 percent of the cost, for up to 18 months. This requirement is often referred to as COBRA benefits, named after the Consolidated Omnibus Budget Reconciliation

\footnotetext{
${ }^{28}$ They are husband's age, wife's age, husband 65 or over, wife 65 or over, husband 62 to 64 , and wife 62 to 64 .
} 
Act of 1985. Forty of the fifty U.S. states have enacted state laws amplifying COBRA by lowering the employer size requirement.(Kaiser Family Foundation 2007) A few states have extended the benefits beyond 18 months for all employees in the state ${ }^{29}$ Six states have addressed the concerns of retirees specifically by requiring former employers of retirees who are near Medicare eligible age to offer continuation coverage until they reach the age of $65{ }^{30}$ Unfortunately, the unrestricted HRS data does not include information on the state that a respondent lives in. The HRS does provide data on the region in which the respondents live, but the states enacting additional continuation laws are not localized to any single region. Generally, the take up rate for those who qualify for COBRA benefits is relatively low, with just over one in five exercising the option. (Flynn 1994)

Though there is not a direct question in the HRS that asks respondents if they are taking advantage of COBRA to continue their benefits, the definition of health insurance risk can be modified to incorporate the possibility that COBRA benefits play a significant role. Specifically, rather than defining "at risk" as those who depend on EPHI without an offer of RHI and will still be under 65 years of age when next observed, I lower the cut-off age by 18 months to 63 years, six months of age in the following wave 31 After that age, a husband or wife could use COBRA to extend health insurance benefits to age 65 at which point he or she will be eligible for Medicare. Columns 1 and 2 in Appendix Table 1 replicate the analysis of a husband's decision to retire using the modified definitions of risk for each spouse. Compared to the original results in Table 5, the MMEs for most risk variables are only slightly different. Overall, the similar importance of husbands' and wives' risk in estimating the likelihood that a husband retires remains true.

\footnotetext{
${ }^{29} \mathrm{CT}, \mathrm{MA}, \mathrm{NH}, \mathrm{NJ}, \mathrm{NY}, \mathrm{TX}, \mathrm{MN}, \mathrm{ND}, \mathrm{SD}, \mathrm{CA}$, and NV extend health insurance benefits to 36 months, FL to 29 months, and IL to 24 months.

${ }^{30}$ They are IL, LA, MD, MO, NH, and OR.

${ }^{31}$ For example, someone who is currently 62 (and thus 64 at the next wave) could be deemed at risk under the original definition but would not be at risk under the definition that incorporates COBRA.
} 


\section{Other Measures of Health}

Appendix Table 3 examines the impact if self-rated health is replaced by two alternative measures of health. In columns 1 and 2, self-rated health is replaced by an indicator for the existence of a health condition. An individual is identified as having poor health if they report ever having any of the following health conditions: diabetes, cancer, lung disease, heart problems, or a stroke. Almost one-quarter of the sample has one of these listed conditions while only ten to 15 percent rate their health as fair or poor. Columns 3 and 4 present the results if overnight hospital stays in the previous twelve months are used as an indicator of poor health. Columns 1 and 3 show that the choice of health measures has very little impact on the MMEs of the health insurance risk variables as the MMEs are similar to those in Table 5. That said, the existence of a health condition for the wife has a significantly negative association with a husband's decision to retire, while her self-rated health and a hospital stay in the last year do not. When interaction terms are included in columns 2 and 4 , their inclusion does not have the same impact as it did in the case of self-rated health (Table 7) ${ }^{32}$ Unlike the specification using self-rated health, the MME on the wife's sole risk identifier remains significantly negative and the interaction term does not have a significantly negative MME when either of the two alternative measures of health are used. The difference in results here depending on which health proxy is used is not new to economic literature. Bound (1991) discusses the variation in results when using self-reported health or other health measures in retirement models but do not find one measure to be better than any other.

\footnotetext{
${ }^{32}$ As with the MME for the interaction terms in Table 7, adjustments have been made to reflect the true magnitude of the interaction term's marginal effect as described in Ai and Norton (2003).
} 


\section{References}

Ai, Chunrong and Edward C. Norton, "Interaction Terms in Logit and Probit Models," Economic Letters, 2003, 80, 123-129.

Becker, Gary, "A Theory of Social Interactions," Journal of Political Economy, 1974, 82 (6), 1063-1094.

Blau, David and Donna Gilleskie, "Retiree Health Insurance and Labor Force Outcomes of Older Men in the 1990's," Review of Economics and Statistics, 2001, 83 (1), 64-80.

Blau, David M. and Donna B. Gilleskie, "Health Insurance and Retirement of Married Couples," Journal of Applied Econometrics, 2006, 21 (7), 935-953.

Bound, John, "Self-Reported versus Objective Measures of Health in Retirement Models," Journal of Human Resources, 1991, 26 (1), 106-38.

Buchmueller, Thomas and Robert Valletta, "The Effect of Health Insurance on Married Female Labor Supply," Journal of Human Resources, 1999, 34 (1), 42-70.

— , Richard W Johnson, and Anthony T Lo Sasso, "Trends in Retiree Health Insurance, 1997-2003," Health Affairs, 2006, 25 (6), 1507-1516.

Coile, Courtney, "Retirement Incentives and Couples' Retirement Decisions," Topics in Economic Analysis 85 Policy, 2004, 4 (1).

and Jonathan Gruber, "Social Security Incentives for Retirement," in David A. Wise, ed., Themes in the Economics of Aging, Chicago: University of Chicago Press, 2001.

Congdon-Hohman, Joshua M, "The Impact of Health Insurance Availability on Retirement Decision Reversals," Working Paper 2006-137, Michigan Retirement Research Center 2006.

Flynn, Patrice, "COBRA qualifying Events \& Elections, 1987-1991," Inquiry, 1994, Summer, 215-20.

French, Eric and John Bailey Jones, "The Effects of Health Insurance and Self-Insurance on Retirement Behavior," Econometrica, 2011, 79 (3), 693-732.

Gruber, Jonathan and Bridgitte C. Madrian, "Health Insurance and Early Retirement: Evidence from the Availability of Continuation Coverage," in David A. Wise, ed., Advances in the Economics of Aging, Chicago: University of Chicago Press, 1996.

and _ _ "Health Insurance, Labor Supply, and Job Mobility: A Critical Review of the Literature," Working Paper 8817, National Bureau of Economic Research 2002.

and Brigitte C. Madrian, "Health Insurance Availability and the Retirement Decision," American Economic Review, 1995, 85 (4), 86-102. 
Gustman, Alan L. and Thomas L. Steinmeier, "Employer-Provided Health Insurance and Retirement Behavior," Industrial and Labor Relations Review, 1994, 48 (1), 124140 .

_ _ and _ _ "What People Don't Know About Their Pension and Social Security," in William Gale, John Shoven, and Mark Warshawsky, eds., Public Policy and Private Pensions, Washington, DC: Brookings Institute, 2001.

Henriques, Alice M., "How Does Social Security Claiming Respond to Incentives? Considering Husbands' and Wives' Benefits Separately," Working Paper 2012-19, Board of Governors of the Federal Reserve System 2012.

Kaiser Family Foundation, "The Current State of Retiree Health Benefits," Publication Number 60612002.

__ , "Expanded COBRA Continuation Coverage for Small Firm Employees," Technical Report 2007.

__ , "Focus on Health Reform: Summary of New Health Reform Law," Publication Number 8061 April 19, 2011.

Kaiser Family Foundation and Health Research and Education Trust, "Employer Health Benefits: 2007 Annual Survey," Publication Number 76722007.

Kaiser Family Foundation and Hewitt Associates, "Retiree Health Benefits Now and in the Future: Findings from the Kaiser/Hewitt 2003 Survey on Retiree Health Benefits," Publication Number 61052004.

Kapur, Kanika and Jeannette Rogowski, "The Role of Health Insurance in Joint Retirement Among Married Couples," Industrial and Labor Relations Review, 2007, 60 (3), 397-407.

__ and _ _ "How Does Health Insurance Affect the Retirement Behavior of Women?," Inquiry, 2011, 48 (1), 51-67.

Karoly, Lynn A. and Jeannette A. Rogowski, "The Effect of Access to Post-Retirement Health Insurance on the Decision to Retire Early," Industrial and Labor Relations Review, 1994, 48 (1), 103-123.

Kennedy, Kelly, "Medicare age hike could save $\$ 125 \mathrm{~B}$ over 10 years," USA Today, July 14, 2011.

Lumsdaine, Robin L, James H. Stock, and David A Wise, "Pension Plan Provisions and Retirement: Men and Women, Medicare, and Models," in David A. Wise, ed., Studies in the Economics of Aging, Chicago: University of Chicago Press, 1994, pp. 181232.

Lundberg, Shelly and Robert A. Pollack, "Bargaining and Distribution in Marriage," The Journal of Economic Perspectives, 1996, 10 (4), 139-158. 
Madrian, Brigitte C., "The Effect of Health Insurance on Retirement," Brookings Papers on Economic Activity, 1994, 1, 181-232.

and Nancy D. Beaulieu, "Does Medicare Eligibility Affect Retirement," in David A. Wise, ed., Inquires in the Economics of Aging, Chicago: University of Chicago Press, 1998, pp. 109-131.

Maestas, Nicole, "Back to Work: Expectations and Realizations of Work after Retirement," Journal of Human Resources, 2010, 45 (3), 718-748.

Merlis, Mark, "Fundamentals of Underwriting in the Nongroup Health Insurance Market: Access to Coverage and Options for Reform," Background Paper, National Health Policy Forum 2005.

Pauly, Mark and Len Nichols, "The Nongroup Market: Short on Facts, Long on Opinion and Policy Disputes," Technical Report, Health Affairs 2002.

Pollitz, Karen, Richard Sorian, and Kathy Thomas, "How Accessible is Individual Health Insurance for Consumers in Less-than-Perfect Health?," Technical Report 3133, Kaiser Family Foundation 2001.

Rogowski, Jeannette and Lynn Karoly, "Health Insurance and Retirement Behavior: Evidence from the Health and Retirement Survey," Journal of Health Economics, 2000, 19 (4), 529-539.

Rust, John and Christopher Phelan, "How Social Security and Medicare Affect Retirement Behavior in a World of Incomplete Markets," Econometrica, 1997, 65 (4), $781-831$.

Samuelson, Paul A., "Social Indifference Curves," Quarterly Journal of Economics, 1956, $70(1), 1-22$.

Sass, Steven A., Wei Sun, and Anthony Webb, "Why Do Married Men Claim Social Security Benefits So Early? Ignorance or Caddishness?," Working Paper 2007-17, Center for Retirement Research at Boston College 2007.

Schur, Claudia L., Marc L. Berk, Gail R. Wilensky, and Jean Paul Gagnon, "Paying for Health Care in Retirement: Workers' Knowledge of Benefits and Expenses," Health Affairs, Supplemental Web Exclusive, 2004, 23, W4-385-95.

St. Clair, Patricia, "RAND HRS Data Documentation, Version H," Documentation, RAND Labor \& Population Program 2008.

Strumpf, Erin, "Employer-Sponsored Health Insurance of Early Retirees: Impacts on Retirement, Health, and Health Care," International Journal of Health Care Finance and Economics, 2010, 10, 105-147. 
Table 1

Sample Restrictions

Number of Number of

Households Observations

\section{General Restrictions:}

Age eligible men or men with an age eligible spouse 6875

Married currently and when last interviewed $\quad 6070$

34440

Currently working and never retired

4388

29220

Not self-employed

3611

14399

Individual or spouse reports EPHI from his or her employer

3208

11110

Data Availability Restrictions:

Non-missing health insurance source information for husband

3166

9618

Non-missing health insurance source information for spouse

9092

Detailed pension data available

3052

8634

No non-missing control variables and weights

3044

8442

8417 
Table 2

Qualifications for "At Risk" of Losing Health Insurance upon a Husband's Retirement

Percent of

Analysis Sample

Qualifications for husband to be identified as "at risk":

Husband is under 65 years of age $\quad 91.0 \%$

Husband has EPHI from own employer $\quad 79.6 \%$

Husband has EPHI from own employer but not offered RHI $\quad 29.8 \%$

Wife does not have EPHI from her own employer

All of the above are true

$62.2 \%$

$20.2 \%$

Qualifications for wife to be identified as "at risk":

Wife is under 65 years of age $\quad 95.0 \%$

Wife has EPHI from husband's employer only $\quad 55.7 \%$

Wife has EPHI from husband's employer but no offer of RHI $\quad 21.3 \%$

All of the above are true

$20.3 \%$

Analysis Sample: Married, husband not previously retired and not self-employed, HRS ageeligible, and at least one spouse with EPHI

Note: Values are weighted based on HRS household sampling weights. 
Table 3

Share "At Risk" of Losing Health Insurance and Corresponding Retirement Rates

\begin{tabular}{ccc}
\hline $\begin{array}{c}\text { Categorization of the "Risk" of } \\
\text { Losing Health Insurance } \\
\text { if Husband Retires }\end{array}$ & $\begin{array}{c}\text { Share of Sample } \\
\text { in } \\
\text { All Waves }\end{array}$ & $\begin{array}{c}\text { Retirement Rate } \\
\text { in } \\
\text { All Waves }\end{array}$ \\
\hline $\begin{array}{c}\text { Neither spouse is at risk } \\
\text { Husband is at risk }\end{array}$ & $76.9 \%$ & $18.0 \%$ \\
Wife is at risk & $20.2 \%$ & $9.9 \%$ \\
Both spouses are at risk & $20.3 \%$ & $12.1 \%$ \\
$\begin{array}{c}\text { Husband is at risk } \\
\text { but not the wife } \\
\text { Wife is at risk } \\
\text { but not the husband }\end{array}$ & $17.5 \%$ & $10.1 \%$ \\
& $2.8 \%$ & $9.1 \%$ \\
\end{tabular}

Analysis Sample: Married, husband not previously retired and not self-employed, HRS age-eligible, and at least one spouse with EPHI

Note: Values are weighted based on HRS household sampling weights. 
Table 4

Sample Means by Categorization of a Household's "Risk" of Losing Health Insurance if the Husband Retires

\begin{tabular}{|c|c|c|c|c|}
\hline & $\begin{array}{l}\text { Neither } \\
\text { at Risk }\end{array}$ & $\begin{array}{l}\text { Both } \\
\text { at Risk }\end{array}$ & $\begin{array}{c}\text { Husband Only } \\
\text { at Risk }\end{array}$ & $\begin{array}{c}\text { Wife Only } \\
\text { at Risk }\end{array}$ \\
\hline Husband's age & 59.4 & $58.2^{* * *}$ & 59.0 & $64.0^{* * *}$ \\
\hline Wife's age & 56.1 & $55.3^{* * *}$ & $59.3^{* * *}$ & $58.4^{* * *}$ \\
\hline Husband is between 62 and 64 & $19.9 \%$ & $19.9 \%$ & $27.3 \% * * *$ & $9.5 \% * * *$ \\
\hline Wife is between 62 and 64 & $10.4 \%$ & $8.6 \% *$ & $6.7 \% *$ & $35.3 \% * * *$ \\
\hline Husband is over 65 & $12.8 \%$ & $0.0 \% * * *$ & $0.0 \% * * *$ & $62.5 \% * * *$ \\
\hline Wife is over 65 & $6.7 \%$ & $0.0 \% * * *$ & $33.6 \% * * *$ & $0.0 \% * * *$ \\
\hline Husband's self-rated health is fair or poor & $11.5 \%$ & $13.2 \% *$ & $18.6 \% * * *$ & $15.3 \% *$ \\
\hline Wife's self-rated health is fair or poor & $13.8 \%$ & $17.6 \% * * *$ & $41.9 \% * * *$ & $17.8^{*}$ \\
\hline Wife is retired & $11.5 \%$ & $11.3 \%$ & $35.2 \% * * *$ & $18.5 \% * * *$ \\
\hline Husband reports any pension & $79.7 \%$ & $84.4 \% * * *$ & $64.4^{* * *}$ & $68.0 \% * * *$ \\
\hline Household non-housing wealth in 100k's (2000 Dollars) & 0.201 & 0.171 & 0.116 & 0.189 \\
\hline Husband's education: less than high school diploma & $16.4 \%$ & $14.2 \% * *$ & $32.4 \% * * *$ & $20.4 \% *$ \\
\hline Husband's education: high school diploma & $34.6 \%$ & $39.1 \% * * *$ & $33.6 \%$ & $37.1 \%$ \\
\hline Husband's education: less than college degree & $20.9 \%$ & $19.0 \%$ & $14.6 \% * *$ & $15.3 \% * *$ \\
\hline Husband's education: college degree & $27.9 \%$ & $27.6 \%$ & $19.4 \% * * *$ & $26.9 \%$ \\
\hline Wife's education: less than high school diploma & $13.7 \%$ & $16.7 \% * * *$ & $35.2 \% * * *$ & $26.2 \% * * *$ \\
\hline Wife's education: high school diploma & $33.4 \%$ & $35.7 \%$ & $30.4 \%$ & $35.3 \%$ \\
\hline Wife's education: less than college degree & $24.3 \%$ & $25.2 \%$ & $19.4 \% *$ & $19.6 \% *$ \\
\hline Wife's education: college degree & $20.5 \%$ & $16.3 \% * * *$ & $14.2 \% * *$ & $14.9 \% * *$ \\
\hline Observations & 6613 & 1276 & 253 & 275 \\
\hline
\end{tabular}

Note: Astericks represent the statistical difference between the associated mean and the mean when neither spouse is at risk based on a simple t-test: * significant at $10 \%$; ** significant at $5 \%$; *** significant at $1 \%$.

Analysis Sample: Married, husband not previously retired and not self-employed, HRS ageeligible, and at least one spouse with EPHI 
Table 5

The Mean Marginal Effects (MMEs) of Both Spouses' Health Insurance Risk on Husbands' Retirements

\begin{tabular}{|c|c|c|c|c|c|c|}
\hline & $\begin{array}{c}1 \\
\text { Husband's } \\
\text { Risk Only }\end{array}$ & $\begin{array}{c}2 \\
\text { Husband's } \\
\text { Risk and } \\
\text { Wife's Non- } \\
\text { shared Risk }\end{array}$ & $\begin{array}{c}3 \\
\text { Fully } \\
\text { Exclusive } \\
\text { Risk } \\
\text { Categories }\end{array}$ & $\begin{array}{l}\text { Husband's } \\
\text { Risk Only }\end{array}$ & $\begin{array}{c}5 \\
\text { Husband's } \\
\text { Risk and } \\
\text { Wife's Non- } \\
\text { shared Risk }\end{array}$ & $\begin{array}{c}6 \\
\text { Fully } \\
\text { Exclusive } \\
\text { Risk } \\
\text { Categories }\end{array}$ \\
\hline $\begin{array}{l}\text { Husband "at risk" of losing health } \\
\text { insurance if he retires }\end{array}$ & $\begin{array}{l}-0.083^{* * *} \\
{[0.010]}\end{array}$ & $\begin{array}{c}-0.081^{* * *} \\
{[0.010]}\end{array}$ & & $\begin{array}{c}-0.066^{* * *} \\
{[0.012]}\end{array}$ & $\begin{array}{c}-0.066^{* * *} \\
{[0.011]}\end{array}$ & \\
\hline $\begin{array}{l}\text { Both "at risk" of losing health } \\
\text { insurance if husband retires }\end{array}$ & & & $\begin{array}{c}-0.079^{* * *} \\
{[0.010]}\end{array}$ & & & $\begin{array}{c}-0.061^{* * *} \\
{[0.012]}\end{array}$ \\
\hline $\begin{array}{l}\text { Only husband "at risk" of losing } \\
\text { health insurance if he retires }\end{array}$ & & & $\begin{array}{c}-0.090^{* * *} \\
{[0.018]}\end{array}$ & & & $\begin{array}{c}-0.101 * * * \\
{[0.021]}\end{array}$ \\
\hline $\begin{array}{l}\text { Only wife "at risk" of losing } \\
\text { health insurance if husband retires }\end{array}$ & & $\begin{array}{l}0.051^{*} \\
{[0.028]}\end{array}$ & $\begin{array}{l}0.051^{*} \\
{[0.028]}\end{array}$ & & $\begin{array}{c}-0.053^{* *} \\
{[0.022]}\end{array}$ & $\begin{array}{c}-0.052^{* *} \\
{[0.022]}\end{array}$ \\
\hline Wife is retired & & & & $\begin{array}{c}0.069^{* * *} \\
{[0.017]}\end{array}$ & $\begin{array}{c}0.070^{* * *} \\
{[0.017]}\end{array}$ & $\begin{array}{c}0.072^{* * *} \\
{[0.017]}\end{array}$ \\
\hline $\begin{array}{l}\text { Husband has a pension plan (DB, } \\
\text { DC, or both) }\end{array}$ & & & & $\begin{array}{c}0.038^{* * *} \\
{[0.011]}\end{array}$ & $\begin{array}{c}0.038^{* * *} \\
{[0.011]}\end{array}$ & $\begin{array}{c}0.037^{* * *} \\
{[0.011]}\end{array}$ \\
\hline $\begin{array}{l}\text { Husband's age in years at next } \\
\text { wave (NW) }\end{array}$ & & & & $\begin{array}{c}0.017^{* * * *} \\
{[0.002]}\end{array}$ & $\begin{array}{c}0.017^{* * * *} \\
{[0.002]}\end{array}$ & $\begin{array}{c}0.017^{* * *} \\
{[0.002]}\end{array}$ \\
\hline Wife's age in years at NW & & & & $\begin{array}{c}0.002 \\
{[0.001]}\end{array}$ & $\begin{array}{c}0.001 \\
{[0.001]}\end{array}$ & $\begin{array}{c}0.001 \\
{[0.001]}\end{array}$ \\
\hline $\begin{array}{l}\text { Husband will be between } 62 \& 64 \\
\text { years old at NW }\end{array}$ & & & & $\begin{array}{c}0.135^{* * *} \\
{[0.019]}\end{array}$ & $\begin{array}{c}0.134^{* * *} \\
{[0.019]}\end{array}$ & $\begin{array}{c}0.134^{* * *} \\
{[0.019]}\end{array}$ \\
\hline $\begin{array}{l}\text { Wife will be between } 62 \& 64 \text { years } \\
\text { old at NW }\end{array}$ & & & & $\begin{array}{l}-0.009 \\
{[0.015]}\end{array}$ & $\begin{array}{l}-0.007 \\
{[0.015]}\end{array}$ & $\begin{array}{l}-0.007 \\
{[0.015]}\end{array}$ \\
\hline $\begin{array}{l}\text { Husband will be } 65 \text { years old or } \\
\text { older at NW }\end{array}$ & & & & $\begin{array}{c}0.066^{* * *} \\
{[0.024]}\end{array}$ & $\begin{array}{c}0.075^{* * *} \\
{[0.025]}\end{array}$ & $\begin{array}{c}0.073^{* * *} \\
{[0.025]}\end{array}$ \\
\hline $\begin{array}{l}\text { Wife will } 65 \text { years old or older } \\
\text { at NW }\end{array}$ & & & & $\begin{array}{l}-0.027 \\
{[0.018]}\end{array}$ & $\begin{array}{c}-0.033^{*} \\
{[0.018]}\end{array}$ & $\begin{array}{l}-0.028 \\
{[0.019]}\end{array}$ \\
\hline $\begin{array}{l}\text { Husband's self-rated health } \\
\text { is fair/poor }\end{array}$ & & & & $\begin{array}{c}0.056^{* * *} \\
{[0.016]}\end{array}$ & $\begin{array}{c}0.056^{* * *} \\
{[0.016]}\end{array}$ & $\begin{array}{c}0.056^{* * *} \\
{[0.016]}\end{array}$ \\
\hline Wife's self-rated health is fair/poor & & & & $\begin{array}{c}0.003 \\
{[0.014]}\end{array}$ & $\begin{array}{c}0.002 \\
{[0.014]}\end{array}$ & $\begin{array}{c}0.004 \\
{[0.014]}\end{array}$ \\
\hline $\begin{array}{l}\text { Real total non-housing } \\
\text { assets (in 100k's) }\end{array}$ & & & & $\begin{array}{l}-0.004 \\
{[0.004]}\end{array}$ & $\begin{array}{l}-0.004 \\
{[0.004]}\end{array}$ & $\begin{array}{l}-0.004 \\
{[0.004]}\end{array}$ \\
\hline $\begin{array}{l}\text { Husband's educational attainment } \\
\text { is less than high school diploma }\end{array}$ & & & & $\begin{array}{l}-0.018 \\
{[0.014]}\end{array}$ & $\begin{array}{l}-0.018 \\
{[0.014]}\end{array}$ & $\begin{array}{l}-0.018 \\
{[0.014]}\end{array}$ \\
\hline $\begin{array}{l}\text { Husband's educational attainment } \\
\text { is some college but no degree }\end{array}$ & & & & $\begin{array}{l}-0.003 \\
{[0.013]}\end{array}$ & $\begin{array}{l}-0.004 \\
{[0.013]}\end{array}$ & $\begin{array}{l}-0.004 \\
{[0.013]}\end{array}$ \\
\hline $\begin{array}{l}\text { Husband's educational attainment } \\
\text { is college degree or more }\end{array}$ & & & & $\begin{array}{l}-0.018 \\
{[0.013]}\end{array}$ & $\begin{array}{l}-0.018 \\
{[0.013]}\end{array}$ & $\begin{array}{l}-0.018 \\
{[0.013]}\end{array}$ \\
\hline $\begin{array}{l}\text { Wife's educational attainment is } \\
\text { less than high school diploma }\end{array}$ & & & & $\begin{array}{l}-0.007 \\
{[0.015]}\end{array}$ & $\begin{array}{l}-0.006 \\
{[0.015]}\end{array}$ & $\begin{array}{l}-0.005 \\
{[0.015]}\end{array}$ \\
\hline $\begin{array}{l}\text { Wife's educational attainment is } \\
\text { some college but no degree }\end{array}$ & & & & $\begin{array}{l}-0.009 \\
{[0.012]}\end{array}$ & $\begin{array}{l}-0.009 \\
{[0.012]}\end{array}$ & $\begin{array}{l}-0.009 \\
{[0.012]}\end{array}$ \\
\hline $\begin{array}{l}\text { Wife's educational attainment is } \\
\text { college degree or more }\end{array}$ & & & & $\begin{array}{l}-0.019 \\
{[0.014]}\end{array}$ & $\begin{array}{l}-0.019 \\
{[0.014]}\end{array}$ & $\begin{array}{l}-0.019 \\
{[0.014]}\end{array}$ \\
\hline Observations & 8417 & 8417 & 8417 & 8417 & 8417 & 8417 \\
\hline
\end{tabular}

Standard errors in brackets, clustered by household. ${ }^{*}$ significant at $10 \%$; ${ }^{* *}$ significant at $5 \%$; $* *$ significant at $1 \%$ Note: Values are weighted based on HRS sampling weights. Wave dummies are included in all specifications.

Sample: Husband or wife had EPHI in the previous wave, husband has not previously retired, husband is not self-employed, and one spouse is age eligible for Initial or War Baby cohort of the HRS. 
Table 6

The Marginal Effect of Health Insurance Risk Evaluated at Different Covariate Values

\begin{tabular}{|c|c|c|c|c|c|c|}
\hline & \multicolumn{6}{|c|}{ "At Risk" of Losing Health Insurance: } \\
\hline & \multicolumn{2}{|c|}{ Both Spouses } & \multicolumn{2}{|c|}{ Husband Only } & \multicolumn{2}{|c|}{ Wife Only } \\
\hline & $\begin{array}{l}\text { Marginal } \\
\text { Effect }\end{array}$ & $\mathrm{SE}$ & $\begin{array}{l}\text { Marginal } \\
\text { Effect }\end{array}$ & SE & $\begin{array}{l}\text { Marginal } \\
\text { Effect }\end{array}$ & $\mathrm{SE}$ \\
\hline \multicolumn{7}{|l|}{ Husband's Age/Wife's Age } \\
\hline At ages $55 / 50$ & $-0.036 * * *$ & {$[0.007]$} & $-0.052^{* * *}$ & {$[0.010]$} & $-0.029 * *$ & {$[0.011]$} \\
\hline At ages $55 / 56$ & $-0.038 * * *$ & {$[0.008]$} & $-0.055^{* * *}$ & {$[0.010]$} & $-0.030 * *$ & {$[0.012]$} \\
\hline At ages $55 / 62$ & $-0.040 * * *$ & {$[0.008]$} & $-0.059 * * *$ & {$[0.011]$} & $-0.032^{* *}$ & {$[0.013]$} \\
\hline At ages $59 / 50$ & $-0.054^{* * *}$ & {$[0.011]$} & $-0.080 * * *$ & {$[0.015]$} & $-0.043^{* *}$ & {$[0.018]$} \\
\hline At ages $59 / 56$ (mean) & $-0.056^{* * *}$ & {$[0.011]$} & $-0.085^{* * *}$ & {$[0.016]$} & $-0.045^{* *}$ & {$[0.018]$} \\
\hline At ages $59 / 62$ & $-0.059 * * *$ & {$[0.012]$} & $-0.089 * * *$ & {$[0.017]$} & $-0.047^{* *}$ & {$[0.019]$} \\
\hline At ages $64 / 50$ & $-0.078 * * *$ & {$[0.017]$} & $-0.123^{* * *}$ & {$[0.026]$} & $-0.063^{* *}$ & {$[0.027]$} \\
\hline At ages $64 / 56$ & $-0.080 * * *$ & {$[0.017]$} & $-0.128^{* * *}$ & {$[0.026]$} & $-0.065^{* *}$ & {$[0.028]$} \\
\hline At ages $64 / 62$ & $-0.083^{* * *}$ & {$[0.018]$} & $-0.132^{* * *}$ & {$[0.028]$} & $-0.067^{* *}$ & {$[0.029]$} \\
\hline \multicolumn{7}{|l|}{ Wife's Retired? } \\
\hline No & $-0.054^{* * *}$ & {$[0.011]$} & $-0.081 * * *$ & {$[0.015]$} & $-0.043^{* *}$ & {$[0.018]$} \\
\hline Yes & $-0.073^{* * *}$ & {$[0.015]$} & $-0.114^{* * *}$ & {$[0.024]$} & $-0.059^{* *}$ & {$[0.025]$} \\
\hline \multicolumn{7}{|l|}{ Husband has a pension? } \\
\hline No & $-0.047^{* * *}$ & {$[0.010]$} & $-0.070 * * *$ & {$[0.014]$} & $-0.038^{* *}$ & {$[0.015]$} \\
\hline Yes & $-0.058^{* * *}$ & {$[0.012]$} & $-0.088^{* * *}$ & {$[0.016]$} & $-0.047^{* *}$ & {$[0.019]$} \\
\hline \multicolumn{7}{|l|}{ Couple's Self-Rated Health } \\
\hline $\begin{array}{l}\text { Both "Good," "Very Good," } \\
\text { or "Excellent" }\end{array}$ & $-0.054^{* * *}$ & {$[0.011]$} & $-0.082^{* * *}$ & {$[0.015]$} & $-0.043^{* *}$ & {$[0.018]$} \\
\hline Husband only "Fair" or "Poor" & $-0.069 * * *$ & {$[0.015]$} & $-0.107^{* * *}$ & {$[0.022]$} & $-0.056^{* *}$ & {$[0.023]$} \\
\hline Wife only "Fair" or "Poor" & $-0.055^{* * *}$ & {$[0.012]$} & $-0.083^{* * *}$ & {$[0.017]$} & $-0.044^{* *}$ & {$[0.018]$} \\
\hline Both "Fair" or "Poor" & $-0.070 * * *$ & {$[0.015]$} & $-0.109 * * *$ & {$[0.023]$} & $-0.057^{* *}$ & {$[0.024]$} \\
\hline \multicolumn{7}{|l|}{$\begin{array}{l}\text { Non-Housing Wealth } \\
\text { in } 2000 \text { Dollars }\end{array}$} \\
\hline$\$ 5,513$ (10th Percentile) & $-0.056^{* * *}$ & {$[0.011]$} & $-0.085^{* * *}$ & {$[0.016]$} & $-0.045^{* *}$ & {$[0.018]$} \\
\hline$\$ 22,825$ (25th Percentile) & $-0.056^{* * *}$ & {$[0.011]$} & $-0.085^{* * *}$ & {$[0.016]$} & $-0.045^{* *}$ & {$[0.018]$} \\
\hline$\$ 70,129$ (50th Percentile) & $-0.056^{* * *}$ & {$[0.011]$} & $-0.085^{* * *}$ & {$[0.016]$} & $-0.045^{* *}$ & {$[0.018]$} \\
\hline$\$ 203,982$ (75th Percentile) & $-0.056^{* * *}$ & {$[0.011]$} & $-0.085^{* * *}$ & {$[0.016]$} & $-0.045^{* *}$ & {$[0.018]$} \\
\hline$\$ 449,518$ (90th Percentile) & $-0.056^{* * *}$ & {$[0.011]$} & $-0.084^{* * *}$ & {$[0.016]$} & $-0.045^{* *}$ & {$[0.018]$} \\
\hline
\end{tabular}

Standard errors in brackets. Clustered by household. * significant at $10 \%$; ${ }^{* *}$ significant at $5 \%$; *** significant at $1 \%$

Note: Values are weighted based on HRS sampling weights. All marginal effects evaluated at the mean of covariates unless otherwise specified.

Sample: Husband or wife had EPHI in the previous wave, husband has not previously retired, husband is not self-employed, and one spouse is age eligible for Initial or War Baby cohort of the HRS 
Table 7

Analysis of Husbands' Retirements with Interactions of Health Measures

\begin{tabular}{|c|c|c|}
\hline & $\begin{array}{c}1 \\
\text { Original } \\
\text { Specification }\end{array}$ & $\begin{array}{c}2 \\
\text { Interactions } \\
\text { Specification }\end{array}$ \\
\hline $\begin{array}{l}\text { Both "At Risk" of Losing Health } \\
\text { Insurance if Husband Retires }\end{array}$ & $\begin{array}{c}-0.061^{* * *} \\
{[0.012]}\end{array}$ & $\begin{array}{l}-0.058 * * * \\
{[0.015]}\end{array}$ \\
\hline $\begin{array}{l}\text { Only Husband "At Risk" of Losing Health } \\
\text { Insurance if He Retires }\end{array}$ & $\begin{array}{c}-0.101^{* * *} \\
{[0.021]}\end{array}$ & $\begin{array}{l}-0.102^{* * *} \\
{[0.023]}\end{array}$ \\
\hline $\begin{array}{l}\text { Only Wife "At Risk" of Losing Health } \\
\text { Insurance if Husband Retires }\end{array}$ & $\begin{array}{c}-0.052^{* *} \\
{[0.022]}\end{array}$ & $\begin{array}{c}-0.04 \\
{[0.025]}\end{array}$ \\
\hline Husband's Health Measure Poor & $\begin{array}{l}0.056^{* * *} \\
{[0.016]}\end{array}$ & $\begin{array}{l}0.056^{* * *} \\
{[0.017]}\end{array}$ \\
\hline Wife's Health Measure Poor & $\begin{array}{c}0.004 \\
{[0.014]}\end{array}$ & $\begin{array}{c}0.01 \\
{[0.016]}\end{array}$ \\
\hline $\begin{array}{l}\text { Interaction of Husband having a Poor Self-rated } \\
\text { Health with Joint Health Insurance Risk }\end{array}$ & & $\begin{array}{r}-0.009 \\
{[0.040]}\end{array}$ \\
\hline $\begin{array}{l}\text { Interaction of Wife having a Poor Self-rated } \\
\text { Health with Joint Health Insurance Risk }\end{array}$ & & $\begin{array}{r}-0.020 \\
{[0.031]}\end{array}$ \\
\hline $\begin{array}{l}\text { Interaction of Husband's Poor Self-rated Health } \\
\text { with Husband Only Health Insurance Risk }\end{array}$ & & $\begin{array}{r}-0.024 \\
{[0.055]}\end{array}$ \\
\hline $\begin{array}{l}\text { Interaction of Wife's Poor Self-rated Health } \\
\text { with Wife Only Health Insurance Risk }\end{array}$ & & $\begin{array}{c}-0.078^{* *} \\
{[0.040]}\end{array}$ \\
\hline $\begin{array}{l}\text { Additional Covariates } \\
\text { Observations }\end{array}$ & $\begin{array}{l}\text { Yes } \\
8417\end{array}$ & $\begin{array}{c}\text { Yes } \\
8417\end{array}$ \\
\hline \multicolumn{3}{|c|}{$\begin{array}{l}\text { Standard errors in brackets. Clustered by household. }{ }^{*} \text { significant at } 10 \% ;{ }^{* *} \text { significant at } \\
5 \% \text {; }{ }^{* *} \text { significant at } 1 \% \\
\text { Note 1: Values are weighted based on HRS sampling weights. Wave dummies included in all } \\
\text { specifications. Additional covariates include whether a wife is retired, whether a husband } \\
\text { has a pension, household wealth, and each spouse's age, age category, and education level. } \\
\text { Note 2: MMEs for interaction terms have been adjust based on Ai and Norton (2003). } \\
\text { Sample: Husband or wife had EPHI in the previous wave, husband has not previously retired, } \\
\text { husband is not self-employed, and one spouse is age eligible for Initial or War Baby cohort } \\
\text { of the HRS }\end{array}$} \\
\hline
\end{tabular}


Table 8

Analysis using Different Subsamples

\begin{tabular}{|c|c|c|c|c|c|c|c|}
\hline & \multicolumn{2}{|c|}{$\begin{array}{c}1 \\
\text { Panel: Wife } 3 \text { to } 5 \\
\text { Years Younger }\end{array}$} & \multicolumn{2}{|c|}{$\begin{array}{c}2 \\
\text { Panel: Wife } 6 \text { Years } \\
\text { or More Younger }\end{array}$} & \multicolumn{3}{|c|}{$\begin{array}{c}3 \\
\text { Cross-sectional: Husband } \\
\text { Age } 63 \text { or } 64\end{array}$} \\
\hline & Mean & MME & Mean & MME & Mean & MME & ATT \\
\hline Both "At Risk" & 0.158 & $\begin{array}{c}-0.074^{* * *} \\
{[0.025]}\end{array}$ & 0.125 & $\begin{array}{c}-0.073^{* * *} \\
{[0.026]}\end{array}$ & 0 & & \\
\hline Only Husband "At Risk" & 0.021 & $\begin{array}{c}-0.184^{* * *} \\
{[0.024]}\end{array}$ & 0.024 & $\begin{array}{c}-0.124^{* * *} \\
{[0.036]}\end{array}$ & 0 & & \\
\hline Only Wife "At Risk" & 0.038 & $\begin{array}{c}-0.068^{* *} \\
{[0.034]}\end{array}$ & 0.055 & $\begin{array}{c}-0.063^{*} \\
{[0.033]}\end{array}$ & 0.111 & $\begin{array}{c}-0.119^{*} \\
{[0.071]}\end{array}$ & $\begin{array}{c}-0.129^{* *} \\
{[0.063]}\end{array}$ \\
\hline Observations & & 2,317 & & 2,152 & & 561 & 561 \\
\hline Subsample Retirement Rate & $19.5 \%$ & & $19.7 \%$ & & $42.6 \%$ & & \\
\hline Analysis & & Probit & & Probit & & Probit & $\begin{array}{c}\text { Propensity Scol } \\
\text { Matching }\end{array}$ \\
\hline \multicolumn{8}{|c|}{$\begin{array}{l}\text { Note: Values are weighted based on HRS sampling weights. Wave dummies included in all specifi- } \\
\text { cations. Additional covariates include whether a wife is retired, whether a husband has a pension, } \\
\text { household wealth, and each spouse's age, age category, and education level. Propensity score matching } \\
\text { using the radius (0.1) matching approach. Average effect of treatment on the treated (ATT) values are } \\
\text { found using the Stata package attr.ado and standard errors are found analytically. } \\
\text { Sample: Husband or wife had EPHI in the previous wave, husband has not previously retired, husband } \\
\text { is not self-employed, and one spouse is age eligible for Initial or War Baby cohort of the HRS }\end{array}$} \\
\hline
\end{tabular}


Table 9

Additional Specifications Examining Husbands' Retirements with Job Characteristics

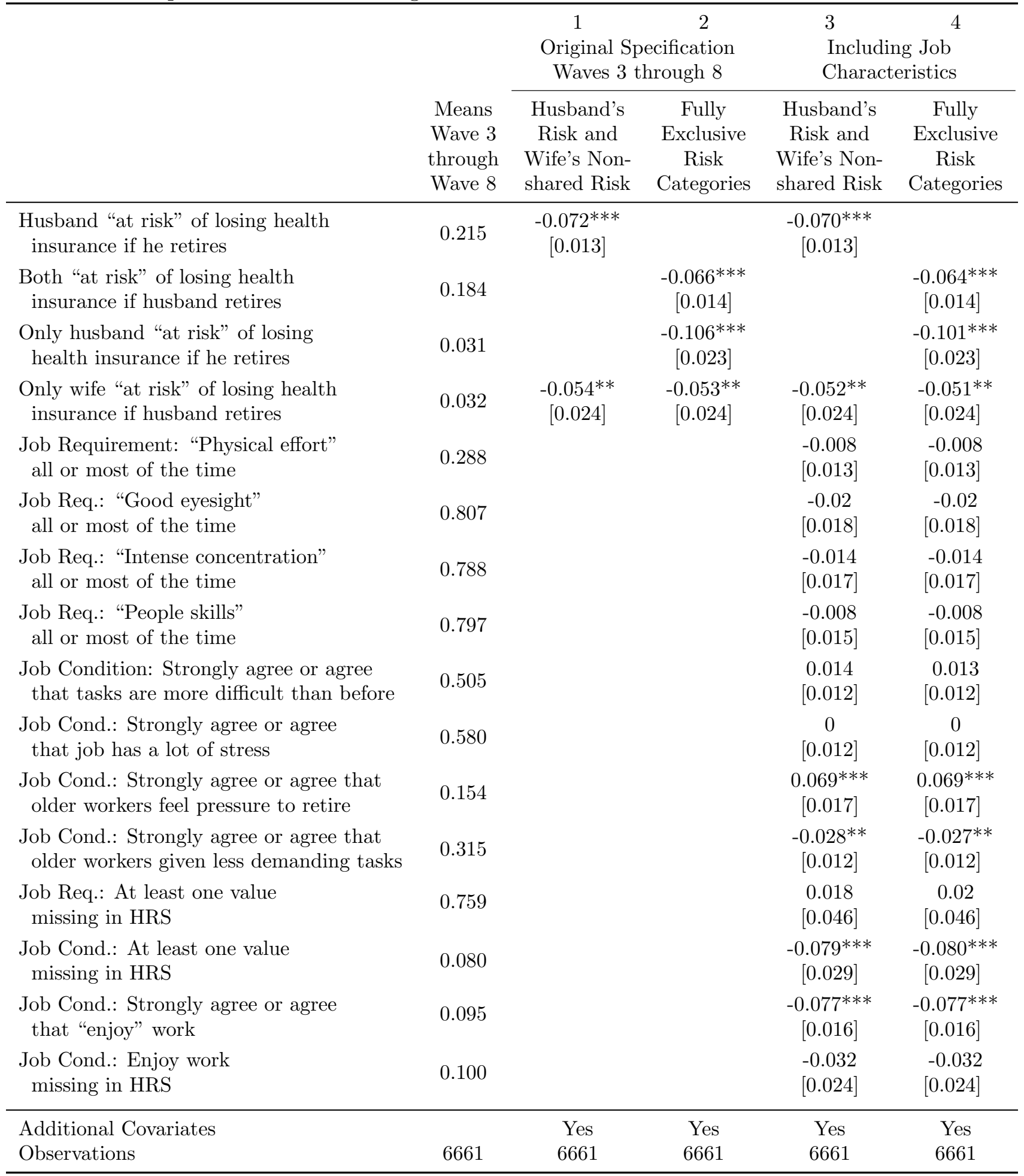

Standard errors in brackets. Clustered by Household. * significant at $10 \%$; ** significant at $5 \%$; *** significant at $1 \%$.

Note: "Enjoy job" is only available in waves 3 through 8 . Values are weighted based on HRS sampling weights. Wave dummies are included in all specifications. Additional covariates include whether a wife is retired, whether a husband has a pension, household wealth, and each spouse's age, age category, self-reported health and education level.

Sample: Husband or wife had EPHI in the previous wave, husband has not previously retired, husband is not self-employed, and one spouse is age eligible for Initial or War Baby cohort of the HRS 


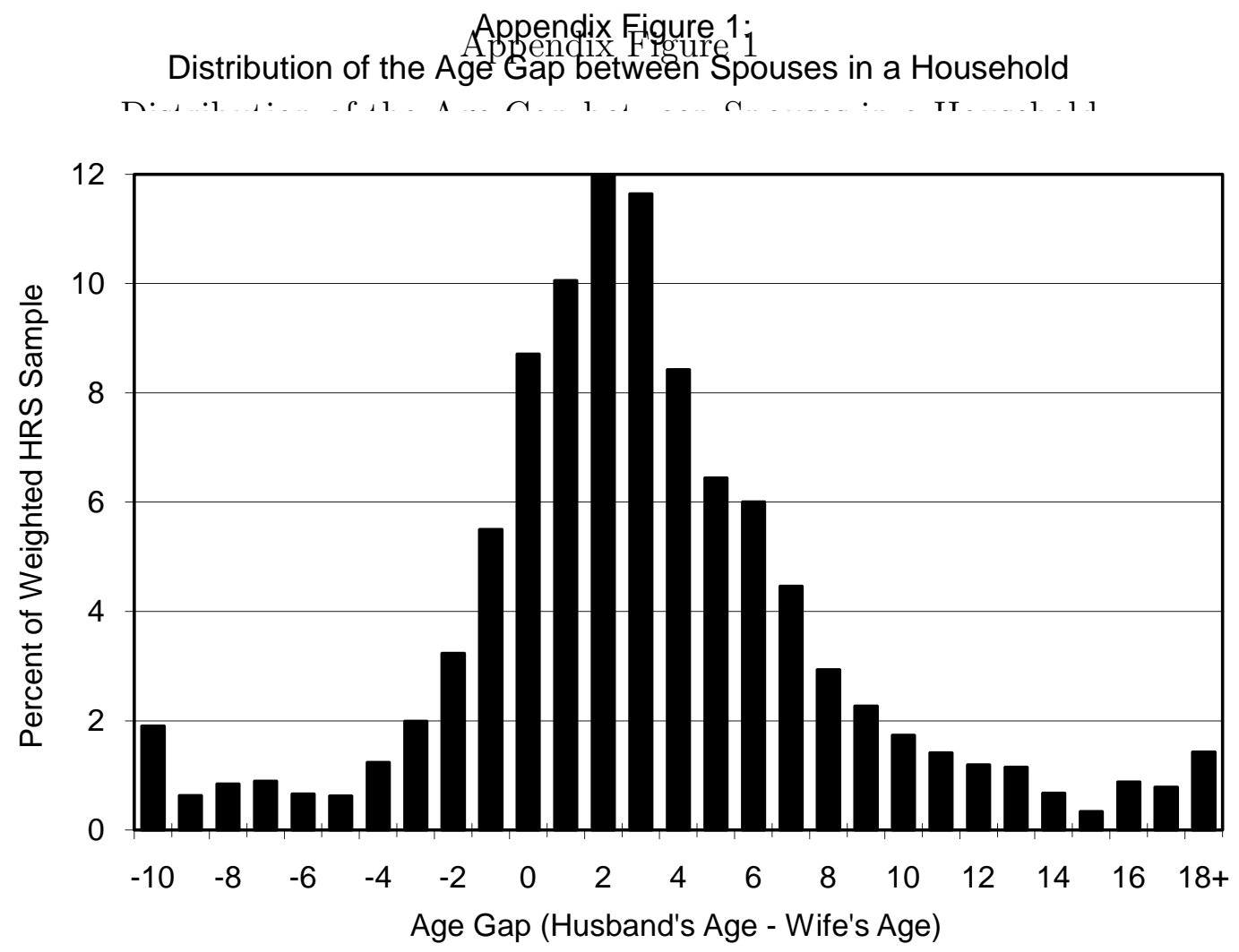

Note: Distribution is based on household weights for HRS households where husband is working at the first interview. 
Figure 1:

An Example of the Optimization Problem Facing a Husband when Health Insurance ispdiakeditarEmployment

An

ment

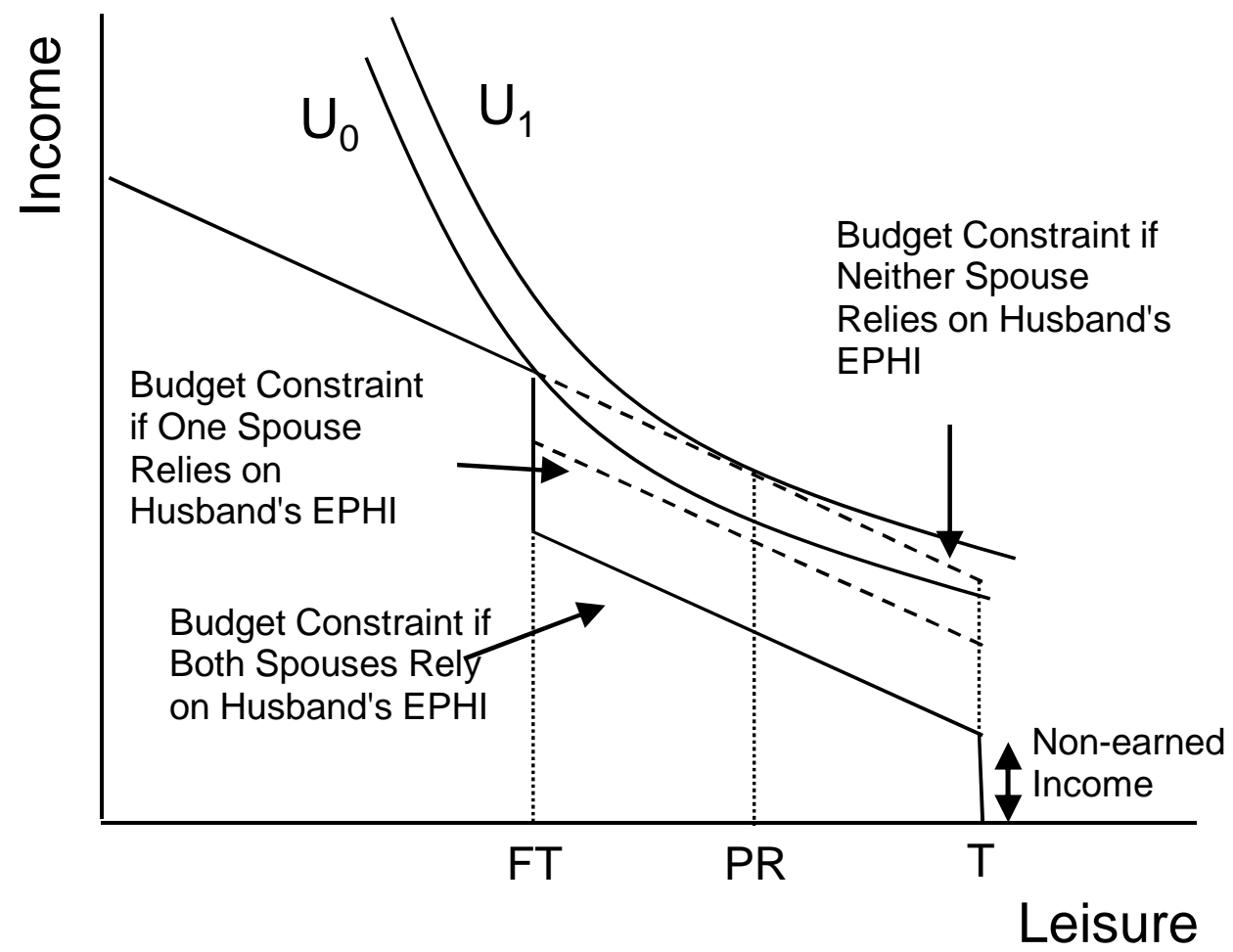


Appendix Table 1

Analysis Using Definitions of Health Insurance Risk that Incorporate Possibility of COBRA

\begin{tabular}{|c|c|c|c|}
\hline & Means & $\begin{array}{c}1 \\
\text { Husband's Risk } \\
\text { and Wife's } \\
\text { Non-shared } \\
\text { Risk using } \\
\text { Max Age 63.5 }\end{array}$ & $\begin{array}{c}2 \\
\text { Fully } \\
\text { Exclusive Risk } \\
\text { Categories } \\
\text { using Maximum } \\
\text { Age } 63.5\end{array}$ \\
\hline $\begin{array}{l}\text { Husband "at risk" of losing health } \\
\text { insurance if he retires }\end{array}$ & 0.188 & $\begin{array}{c}-0.065^{* * *} \\
{[0.012]}\end{array}$ & \\
\hline $\begin{array}{l}\text { Both "at risk" of losing health } \\
\text { insurance if husband retires }\end{array}$ & 0.161 & & $\begin{array}{c}-0.063^{* * *} \\
{[0.013]}\end{array}$ \\
\hline $\begin{array}{l}\text { Only husband "at risk" of losing } \\
\text { health insurance if he retires }\end{array}$ & 0.027 & & $\begin{array}{c}-0.083^{* * *} \\
{[0.024]}\end{array}$ \\
\hline $\begin{array}{l}\text { Only wife "at risk" of losing health } \\
\text { insurance if husband retires }\end{array}$ & 0.033 & $\begin{array}{c}-0.053^{* *} \\
{[0.020]}\end{array}$ & $\begin{array}{c}-0.053^{* *} \\
{[0.020]}\end{array}$ \\
\hline Additional Covariates & & Yes & Yes \\
\hline Observations & 8417 & 8417 & 8417 \\
\hline
\end{tabular}

Note: Values are weighted based on HRS sampling weights. Wave dummies are included in all specifications. Additional covariates include whether a wife is retired, whether a husband has a pension, household wealth, and each spouse's age, age category, self-reported health and education level.

Sample: Husband or wife had EPHI in the previous wave, husband has not previously retired, husband is not self-employed, and one spouse is age eligible for Initial or War Baby cohort of the HRS 


\section{Appendix Table 2}

Decomposition of Changes to Health Insur-

ance Risk Probit MME's when Adding Additional Covariates Using Ordinary Least Squares

A: Analogous Analysis Using Ordinary Least Squares

\begin{tabular}{|c|c|c|c|c|}
\hline \multirow[b]{3}{*}{$\begin{array}{l}\text { Husband "At Risk" of Losing Health } \\
\text { Insurance if He Retires }\end{array}$} & 1 & 2 & \multirow{2}{*}{\multicolumn{2}{|c|}{$\begin{array}{c}3 \\
\text { Fully Exclusive Risk } \\
\text { Categories }\end{array}$}} \\
\hline & \multicolumn{2}{|c|}{$\begin{array}{c}\text { Husband's Risk and } \\
\text { Wife's Non-shared } \\
\text { Risk }\end{array}$} & & \\
\hline & $\begin{array}{c}-0.082 \\
{[0.010]^{* * *}}\end{array}$ & $\begin{array}{c}-0.058 \\
{[0.010]^{* * *}}\end{array}$ & & \\
\hline $\begin{array}{l}\text { Both "At Risk" of Losing Health } \\
\text { Insurance if Husband Retires }\end{array}$ & & & $\begin{array}{c}-0.080 \\
{[0.011]^{* * *}}\end{array}$ & $\begin{array}{c}-0.053 \\
{[0.011]^{* * *}}\end{array}$ \\
\hline $\begin{array}{l}\text { Only Husband "At Risk" of Losing } \\
\text { Health Insurance if He Retires }\end{array}$ & & & $\begin{array}{c}-0.094 \\
{[0.019]^{* * *}}\end{array}$ & $\begin{array}{c}-0.097 \\
{[0.021]^{* * *}}\end{array}$ \\
\hline $\begin{array}{l}\text { Only Wife "At Risk" of Losing } \\
\text { Health Insurance if Husband Retires }\end{array}$ & $\begin{array}{c}0.052 \\
{[0.029]^{*}}\end{array}$ & $\begin{array}{c}-0.054 \\
{[0.027]^{* *}}\end{array}$ & $\begin{array}{c}0.052 \\
{[0.029]^{*}}\end{array}$ & $\begin{array}{c}-0.053 \\
{[0.027]^{* *}}\end{array}$ \\
\hline $\begin{array}{l}\text { Additional Covariates } \\
\text { Observations }\end{array}$ & $\begin{array}{l}\text { No } \\
8417\end{array}$ & $\begin{array}{l}\text { Yes } \\
8417\end{array}$ & $\begin{array}{l}\text { No } \\
8417\end{array}$ & $\begin{array}{l}\text { Yes } \\
8417\end{array}$ \\
\hline
\end{tabular}

B: Net Contribution of Covariate Groupings to the Difference in OLS Coefficients

\begin{tabular}{lccccc}
\hline & $\begin{array}{c}1 \\
\text { Husband's Risk and } \\
\text { Wife's Non-shared } \\
\text { Risk }\end{array}$ & Fully Exclusive Risk Categories \\
\cline { 2 - 6 } & $\begin{array}{c}\text { Husband } \\
\text { at Risk }\end{array}$ & $\begin{array}{c}\text { Wife Only } \\
\text { at Risk }\end{array}$ & $\begin{array}{c}\text { Both at } \\
\text { Risk }\end{array}$ & $\begin{array}{c}\text { Husband } \\
\text { Only at }\end{array}$ & $\begin{array}{c}\text { Wife Only } \\
\text { at Risk }\end{array}$ \\
\hline Difference in OLS Coefficient & -0.024 & 0.107 & -0.028 & 0.002 & 0.106 \\
\hline Husband's Age Variables & -0.030 & 0.096 & -0.033 & -0.014 & 0.095 \\
Wife's Age Variables & 0.000 & 0.003 & 0.000 & -0.002 & 0.003 \\
Spouse Retired & 0.003 & 0.006 & 0.001 & 0.019 & 0.006 \\
Pension \& Wealth & 0.001 & -0.003 & 0.002 & -0.004 & -0.003 \\
Health & 0.002 & 0.002 & 0.001 & 0.003 & 0.002 \\
Husband's Education & 0.000 & 0.000 & 0.000 & 0.000 & 0.000 \\
Wife's Education & 0.000 & 0.001 & 0.000 & 0.000 & 0.001 \\
\hline Difference in Probit MME & -0.021 & 0.104 & -0.018 & 0.011 & 0.103 \\
\hline
\end{tabular}

Notes: "Age Variables" include husband's and wife's raw age, whether 65 or over, and whether between 62 and 65. "Pension and Wealth" includes whether husband has any pension and household's non-housing wealth. "Health" includes husband's and wife's self-rated health. "Education" includes categorical values of "Less than High School," "Some College," and "College Degree" for each spouse. 
Appendix Table 3

Analysis of Husbands' Retirements with Interactions of Other Health Measures

\begin{tabular}{|c|c|c|c|c|}
\hline \multirow[b]{2}{*}{$\begin{array}{l}\text { Both "at risk" of losing health } \\
\text { insurance if husband retires }\end{array}$} & $\begin{array}{c}1 \\
\text { Health } \mathrm{C}\end{array}$ & onditions & \multicolumn{2}{|c|}{$\begin{array}{l}3 \\
\text { Hospital Stay } \\
\text { in Last Year }\end{array}$} \\
\hline & $\begin{array}{c}-0.060 * * * \\
{[0.012]}\end{array}$ & $\begin{array}{c}-0.062^{* * *} \\
{[0.016]}\end{array}$ & $\begin{array}{c}-0.060 * * * \\
{[0.012]}\end{array}$ & $\begin{array}{c}-0.059 * * * \\
{[0.015]}\end{array}$ \\
\hline $\begin{array}{l}\text { Only husband "at risk" of losing health } \\
\text { insurance if he retires }\end{array}$ & $\begin{array}{c}-0.097 * * * \\
{[0.021]}\end{array}$ & $\begin{array}{c}-0.099 * * * \\
{[0.025]}\end{array}$ & $\begin{array}{c}-0.096 * * * \\
{[0.021]}\end{array}$ & $\begin{array}{c}-0.087^{* * *} \\
{[0.023]}\end{array}$ \\
\hline $\begin{array}{l}\text { Only wife "at risk" of losing health } \\
\text { insurance if husband retires }\end{array}$ & $\begin{array}{c}-0.052^{* *} \\
{[0.022]}\end{array}$ & $\begin{array}{c}-0.048^{*} \\
{[0.026]}\end{array}$ & $\begin{array}{c}-0.050^{* *} \\
{[0.023]}\end{array}$ & $\begin{array}{c}-0.049 * * \\
{[0.024]}\end{array}$ \\
\hline Husband's health measure poor & $\begin{array}{c}0.034^{* * *} \\
{[0.011]}\end{array}$ & $\begin{array}{c}0.035^{* * *} \\
{[0.012]}\end{array}$ & $\begin{array}{c}0.041^{* * *} \\
{[0.015]}\end{array}$ & $\begin{array}{c}0.049 * * * \\
{[0.016]}\end{array}$ \\
\hline Wife's health measure poor & $\begin{array}{c}-0.029 * * * \\
{[0.011]}\end{array}$ & $\begin{array}{c}-0.031^{* * *} \\
{[0.012]}\end{array}$ & $\begin{array}{l}-0.011 \\
{[0.013]}\end{array}$ & $\begin{array}{r}-0.017 \\
{[0.014]}\end{array}$ \\
\hline $\begin{array}{l}\text { Interaction of husband's poor health } \\
\text { measure with joint HI risk }\end{array}$ & & $\begin{array}{l}-0.016 \\
{[0.027]}\end{array}$ & & $\begin{array}{r}-0.043 \\
{[0.033]}\end{array}$ \\
\hline $\begin{array}{l}\text { Interaction of wife's poor health } \\
\text { measure with joint HI risk }\end{array}$ & & $\begin{array}{c}0.027 \\
{[0.027]}\end{array}$ & & $\begin{array}{r}0.039 \\
{[0.034]}\end{array}$ \\
\hline $\begin{array}{l}\text { Interaction of husband's poor health } \\
\text { measure with husband only HI risk }\end{array}$ & & $\begin{array}{l}-0.006 \\
{[0.048]}\end{array}$ & & $\begin{array}{c}-0.105^{* * *} \\
{[0.042]}\end{array}$ \\
\hline $\begin{array}{l}\text { Interaction of wife's poor health } \\
\text { measure with wife only HI risk }\end{array}$ & & $\begin{array}{l}-0.011 \\
{[0.038]}\end{array}$ & & $\begin{array}{l}-0.005 \\
{[0.050]}\end{array}$ \\
\hline $\begin{array}{l}\text { Additional Covariates } \\
\text { Observations }\end{array}$ & $\begin{array}{c}\text { Yes } \\
8397\end{array}$ & $\begin{array}{c}\text { Yes } \\
8397\end{array}$ & $\begin{array}{l}\text { Yes } \\
8414\end{array}$ & $\begin{array}{c}\text { Yes } \\
8414\end{array}$ \\
\hline
\end{tabular}

Standard errors in brackets. Clustered by Household. * significant at $10 \%$; ** significant at $5 \%$; *** significant at $1 \%$

Note 1: Health conditions include ever having diabetes, cancer, lung disease, heart problems, or a stroke. Wave dummies included in all specifications.

Note 2: Values are weighted based on HRS sampling weights. Wave dummies included in all specifications. Additional covariates include whether a wife is retired, whether a husband has a pension, household wealth, and each spouse's age, age category, and education level.

Note 3: MMEs for interaction terms have been adjust based on Ai and Norton (2003).

Sample: Husband or wife had EPHI in the previous wave, husband has not previously retired, husband is not self-employed, and one spouse is age eligible for Initial or War Baby cohort of the HRS 
Appendix Table 4

Additional Specification Examining Husbands' Retirements with Pension Types

\begin{tabular}{lcc}
\hline & 1 & 2 \\
& $\begin{array}{c}\text { Husband's } \\
\text { Risk and } \\
\text { Wife's Non- } \\
\text { shared Risk }\end{array}$ & $\begin{array}{c}\text { Fully } \\
\text { Exclusive } \\
\text { Risk } \\
\text { Categories }\end{array}$ \\
\hline Husband "at risk" of losing health & $-0.060^{* * *}$ & \\
insurance if he retires & {$[0.012]$} & \\
Both "at risk" of losing health & & $-0.056^{* * *}$ \\
insurance if husband retires & & {$[0.013]$} \\
Only husband "at risk" of losing & & $-0.089^{* * *}$ \\
health insurance if he retires & {$[0.022]$} \\
Only wife "at risk" of losing & $-0.048^{* *}$ & $-0.047^{* *}$ \\
health insurance if husband retires & {$[0.022]$} & {$[0.022]$} \\
Husband reports both a defined benefit (DB) & $0.051^{* * *}$ & $0.050^{* * *}$ \\
and defined contribution (DC) pension & {$[0.016]$} & {$[0.016]$} \\
Husband reports only a DB pension & $0.085^{* * *}$ & $0.084^{* * *}$ \\
& {$[0.015]$} & {$[0.015]$} \\
Husband reports only a DC pension & $-0.024^{*}$ & $-0.024^{*}$ \\
\hline Additional Covariates & {$[0.013]$} & {$[0.013]$} \\
Observations & Yes & Yes \\
\hline
\end{tabular}

Standard errors in brackets. Clustered by household. ${ }^{*}$ significant at $10 \% ;{ }^{* *}$ significant at $5 \%$; *** significant at $1 \%$.

Note 1: Additional covariates include whether a wife is retired, household wealth, and each spouse's age, age category, self-reported health and education level. Wave dummies are included in all specifications.

Note 2: Values are weighted based on HRS sampling weights.

Sample: Husband or Wife had EPHI in the previous wave, Husband has not previously retired, Husband is not self-employed, and one spouse is age eligible for Initial or War Baby cohort of the HRS 
Appendix Table 5

The Mean Marginal Effects (MMEs) of Both Spouses' Health Insurance Risk on Wives' Retirements

\begin{tabular}{|c|c|c|c|c|}
\hline & $\begin{array}{l}\text { Variable } \\
\text { Means }\end{array}$ & $\begin{array}{l}\text { Wife's } \\
\text { Risk Only }\end{array}$ & $\begin{array}{c}2 \\
\text { Wife's } \\
\text { Risk and } \\
\text { Husband's Non- } \\
\text { shared Risk }\end{array}$ & $\begin{array}{c}3 \\
\text { Fully } \\
\text { Exclusive } \\
\text { Risk } \\
\text { Categories }\end{array}$ \\
\hline $\begin{array}{l}\text { Wife "At Risk" of Losing Health } \\
\text { Insurance if She Retires }\end{array}$ & 0.148 & $\begin{array}{c}-0.068^{* * *} \\
{[0.010]}\end{array}$ & $\begin{array}{c}-0.068^{* * *} \\
{[0.010]}\end{array}$ & \\
\hline $\begin{array}{l}\text { Both "At Risk" of Losing Health } \\
\text { Insurance if Wife Retires }\end{array}$ & 0.065 & & & $\begin{array}{c}-0.072^{* * *} \\
{[0.014]}\end{array}$ \\
\hline $\begin{array}{l}\text { Only Wife "At Risk" of Losing } \\
\text { Health Insurance if She Retires }\end{array}$ & 0.083 & & & $\begin{array}{c}-0.064^{* * *} \\
{[0.012]}\end{array}$ \\
\hline $\begin{array}{l}\text { Only Husband "At Risk" of Losing } \\
\text { Health Insurance if Wife Retires }\end{array}$ & 0.006 & & $\begin{array}{l}-0.019 \\
{[0.040]}\end{array}$ & $\begin{array}{l}-0.019 \\
{[0.040]}\end{array}$ \\
\hline $\begin{array}{l}\text { Additional Covariates } \\
\text { Observations }\end{array}$ & & $\begin{array}{c}\text { Yes } \\
8,594\end{array}$ & $\begin{array}{c}\text { Yes } \\
8,594\end{array}$ & $\begin{array}{c}\text { Yes } \\
8,594\end{array}$ \\
\hline
\end{tabular}

Standard errors in brackets. Clustered by household. * significant at $10 \%$; ${ }^{* *}$ significant at $5 \%$; $* * *$ significant at $1 \%$.

Note 1: Additional covariates include whether a husband is retired, household wealth, and each spouse's age, age category, self-reported health and education level. Wave dummies are included in all specifications.

Note 2: Values are weighted based on HRS sampling weights.

Sample: Husband or Wife had EPHI in the previous wave, wife has not previously retired, wife is not self-employed, and one spouse is age eligible for Initial or War Baby cohort of the HRS 